\title{
Arbuscular Mycorrhizal Fungi
}

Occurrence in Sweden and Interaction with a Plant Pathogenic Fungus in Barley

\author{
Johanna Sjöberg \\ Faculty of Natural Resources and Agricultural Sciences \\ Department of Crop Production Ecology \\ Uppsala
}

Doctoral thesis

Swedish University of Agricultural Sciences

Uppsala 2005 


\section{Acta Universitatis Agriculturae Sueciae}

2005: 33

Cover photos of a barley field at the SLU research station at Offer, a barley root and a hyphae of Glomus intraradices, a barley plant in Switzerland with spot blotch and a spore of Gigaspora margarita. All photos are taken by Johanna Sjöberg (except the spot blotch which is taken by Sara Elfstrand).

ISSN $1652-6880$

ISBN 91-576-7032-3

(C) 2005 Johanna Sjöberg, Uppsala

Tryck: SLU Service/Repro, Uppsala 2005 


\section{To my parents}

\section{Marianne \& Nils-Gunnar Sjöberg}

Med goda idéer är det som med svamp; där man hittar en finns det oftast flera

Okänd

Om du tänker för länge på nästa steg, kommer du tillbringa livet på ett ben Kinesiskt ordspråk 



\section{Abstract}

Sjöberg, J. 2005. Arbuscular mycorrhizal fungi-Occurrence in Sweden and Interaction with a Plant Pathogenic Fungus in Barley. Doctoral dissertation.

ISBN 91-576-7032-3, ISSN 1652-6880.

The potential disease suppressiveness of arbuscular mycorrhizal (AM) fungi of various origins on Bipolaris sorokiniana in barley has been investigated. Firstly, a survey considering the occurrence of AM fungi in arable fields in Sweden were conducted with the aim to exploit site specific genetic resources in relation to disease suppressiveness. Arbuscular mycorrhizal fungi were present at all 45 sampling sites surveyed all over Sweden at densities ranging from 3 up to 44 spores per gram air dried soil. The highest spore density was found in a semi-natural grassland and the lowest were found in a cereal monoculture. The AM fungi were then multiplied in trap cultures in the greenhouse with the aim to use these for studying potential disease suppressiveness. Thus, the effects of the AM fungi trap cultures on the transmission of seed-borne $B$. sorokiniana in barley were investigated, using the trap culture inocula, but also including inocula consisting on spore mixtures. The arbuscular mycorrhizal fungi were able to suppress the transmission of $B$. sorokiniana in aerial parts of barley plants. The degree of suppression varied with the origin of the AM fungal trap cultures. The trap culture inoculum with the highest suppression of the $B$. sorokiniana transmission originated from an organically managed barley field with undersown ley. The two spore-inocula with the best suppression of the pathogen originated from fields with winter wheat and spring barley, respectively.

Eventually, an in vitro method was developed for studying the effect of AM fungal colonisation of roots on the development of foliar diseases and the reaction of the actual host plant of the disease causing organism. Using the developed method, it was indicated that AM fungal colonisation of barley plant suppressed the development of leaf necroses due to $B$. sorokiniana. Further in vitro studies on the interaction between $B$. sorokiniana and arbuscular mycorrhizal fungi showed that $B$. sorokiniana decrease the germination of the AM fungal spores. In conclusion, AM fungi suppress the development of $B$. sorokiniana in barley. My data suggest that for biocontrol of $B$. sorokiniana AM fungi should be considered.

Key words: Biocontrol, Bipolaris sorokiniana, Glomeromycota, Common root rot, Spot blotch

Author's address: Johanna Sjöberg, Department of Crop Production Ecology, SLU, Box 7043, SE-750 07 Uppsala, Sweden. E-mail address: Johanna.Sjoberg@evp.slu.se 


\section{Svensk sammanfattning}

Bipolaris är en växtsjukdomsframkallande svamp som under svenska förhållanden i första hand angriper korn. Svampen sprids främst via utsäde, men det kan även finnas smitta i jord eller luft. Svenska försök har visat skördeförluster på närmare ett halvt ton per hektar. Syftet med mitt doktorandprojekt var att ta reda på om arbuskulär mykorrhizasvamp kan minska angrepp av bipolaris i korn. Arbuskulär mykorrhizasvamp är en svamp som enbart kan leva genom att samverka med växtrötter. Svampen får energi genom växtens fotosyntes och i gengäld hjälper svampen växten att ta upp näring. Svampen har fått sitt namn genom en speciell struktur som kallas "arbuskler". Arbusklerna är förgrenade hyfer i rötternas celler där näringsutbytet sker. Till att börja med inventerades arbuskulär mykorrhizasvamp i svensk åker- och ängsmark, därefter studerades effekten av arbuskulär mykorrhizasvamp från olika fält på utsädesburen bipolaris och sist gjordes en studie för att ta reda på om de båda svamparna har någon direkt inverkar på varandra. Arbuskulär mykorrhizasvamp fanns i samtliga 45 fält där jordprov togs, från Skåne i söder till Norrbotten i norr. Det visar att arbuskulär mykorrhiza har en stor utbredning i svensk jordbruksmark. Växthusstudier visade att arbuskulär mykorrhizasvamp hämmar bipolaris utveckling från utsädessmittan till blad och strån. Mykorrhizasvampar från olika fält var olika effektiv beträffande hämning av bipolaris. Mykorrhizasvampen hämmade bipolaris, trots att det var låg kolonisering av mykorrhizasvampen i rötterna. Det kan tyda på att bipolaris i sin tur hämmar mykorrhizasvampen. I laboratoriestudier visade det sig att bipolaris hämmar groning av den arbuskulär mykorrhizasvampens sporer. Extrakt från mykorrhizasvampen hade däremot ingen inverkan på groning av bipolariskonidier. Dessutom utvecklades en metod för att under sterila former kunna studera effekten av mykorrhizakolonisering av kornrötter på olika sjukdomar på bladen. Med denna metod kunde det påvisas att kolonisering av arbuskulär mykorrhizasvamp hämmade utvecklingen av bipolarisfläckar på bladen. För biologisk bekämpning av bipolaris i korn är det förmodligen möjligt att påverka brukningsmetoderna för att främja groning och aktivitet av de mykorrhizasvampar som har störst förmåga att hämma patogenen. 


\section{Contents}

$\begin{array}{lc}\text { Objectives } & \mathbf{9} \\ \text { Introduction } & \mathbf{9} \\ \text { Arbuscular mycorrhizal fungi } & 10 \\ \text { Taxonomy } & 10 \\ \text { Occurrence } & 11 \\ \text { Colonisation } & 12 \\ \text { Benefits for the AM symbionts } & 13 \\ \text { Agricultural impact on AM fungi } & 14 \\ \text { Plant and AM fungal diversity } & 15 \\ \text { Bipolaris sorokiniana } & 16 \\ \text { Taxonomy } & 16 \\ \text { Diseases and dispersal } & 16 \\ \text { Control measures } & 18 \\ \text { AM fungi in disease control } & 20 \\ \text { Mode of actions in biocontrol with bearing to } & \\ \text { B. sorokiniana and AM fungi } & 20 \\ \text { Material and methods } & \mathbf{2 2} \\ \text { Indigenous AM fungal spores } & 22 \\ \text { Greenhouse experiments } & 23 \\ \text { In vitro studies } & 24 \\ \text { Results and Discussion } & \mathbf{2 6} \\ \text { AM fungi occurrence } & 26 \\ \text { Diversity and symbiotic effectiveness } & 27 \\ \text { AM fungi suppressiveness of B. sorokiniana } & 28 \\ \text { Competition } & 32 \\ \text { Conclusions } & \mathbf{3 4} \\ \text { Abbreviations } & \mathbf{3 5} \\ \text { Glossary of useful terms } & \mathbf{3 5} \\ \text { References } & \mathbf{3 7} \\ \text { Acknowledgements } & \mathbf{5 2}\end{array}$




\section{Appendix}

\section{Paper I-III}

The thesis is based on the following papers;

I. Sjöberg J., Persson P., Mårtensson A., Mattsson L., Adholeya A. \& Alström S. 2004. Occurrence of Glomeromycota spores and some arbuscular mycorrhiza fungal species in arable fields in Sweden. Acta Agriculturae Scandinavica, Section B, Soil and Plant Science 54, 202-212.

II: Sjöberg J., Mårtensson A. \& Persson P. Development of seed-borne Bipolaris sorokiniana in barley in the presence of field populations of arbuscular mycorrhizal fungi. European Journal of Plant Pathology (Accepted after minor revision).

III. Sjöberg J. The plant pathogenic fungus Bipolaris sorokiniana inhibits arbuscular mycorrhizal fungi which in turn suppress disease development in barley. Mycorrhiza (Submitted).

Paper I is reprinted by permission of the publisher 



\section{Objectives}

In this thesis I have studied the occurrence of arbuscular mycorrhizal (AM) fungi in arable fields in Sweden, the influence of AM fungi from different origin on Bipolaris sorokiniana infested barley plants and the mechanisms involved in the interactions. The hypothesis was that the AM fungi can inhibit the transmission of $B$. sorokiniana in barley and that these characters differ with the origin of the AM fungi. A second hypothesis was that the AM fungi and B. sorokiniana affect the germination or hyphal growth of each other in the preinfectious stage in the soil. To test the hypotheses field and laboratory studies have been conducted at different scales; from the field level occurrence of AM fungi in a country to the micro scale of individual fungal hyphae growing on nutrient medium in the laboratory. A series of studies were conducted with the aims to:

- investigate the occurrence and diversity of arbuscular mycorrhizal fungi in arable fields in Sweden (Paper I),

- investigate the influence of AM fungi from different fields on the transmission of seed-borne B. sorokiniana in barley (Paper II),

- study the mechanisms involved in the interactions between $B$. sorokiniana, AM fungi and barley plants (Paper III).

\section{Introduction}

Plants are, by definition, the only higher organisms that can convert the energy of sunlight into stored, usable chemical energy. The farmers are a link through which this energy becomes food to domestic animals and humans. However, not only humans take advantages of this life necessity, but also fungi around the plant roots, among those both harmful- and beneficial organisms, influencing the quality and yield of the crop. The former includes the widespread plant pathogenic fungus Bipolaris sorokiniana that can cause disease in grasses including cereals but occasionally also other taxonomic groups (Wildermuth and MacNamara, 1987). Bipolaris sorokiniana is an important pathogen of barley in the cool climate of North-Western Europe (Jørgensen, 1974; Whittle, 1977; Kurppa, 1984). Only in Scandinavia barley (Hordeum vulgare L.) is cultivated on an area of nearly two million hectare (Statistics Sweden, 2004), mostly spring barley. There has been increasing demand for non-chemical methods of plant disease control, both from consumers and farmers. Extensive uses of pesticides pose a risk for pollution of the environment and the food, with sometimes well-known, sometimes poorly known consequences. The development of plant pathogen resistance to commonly used chemical compounds is another risk factor. An additional threat is that fungicides may reduce plant beneficial organisms. Beside the need of decreasing the use of synthetical chemicals, there is also a need for organic farmers to achieve tools for restricting the negative consequences of the pathogens. 
A few studies have indicated the possibility of arbuscular mycorrhizal (AM) fungi to suppress B. sorokiniana in the roots (Dehn and Dehne, 1986; Thompson and Wildermuth, 1989). The use of AM fungi, either by adding them into the field or by favouring the already existing, could therefore be an interesting alternative or complement to restrict the pathogen.

\section{Arbuscular Mycorrhizal Fungi}

\section{Taxonomy}

The first report that root fungi may be beneficial to plants was observed on Indian pipe (Kamienski, 1881). Frank (1885) named the symbiosis between fungi and roots "Mykorrhizen", from the Greek meaning "fungus root". Amongst the mycorrhizal associations, the AM association is the most common one. Arbuscular mycorrhizal fungi belong to the fungal phylum Glomeromycota (Schüßler et al., 2001). The Glomeromycota is divided into four orders, eight families and ten genera. The genera which include most of the described species are Acaulospora, Gigaspora, Glomus and Scutellospora (Schüßler, 2005). The AM fungi obtain their energy through an obligate symbiosis with vascular plants; the AM, although non-vascular plants also are reported to form the AM (Russell and Bulman, 2005). The AM fungi are named by their formation of highly branched intracellular fungal structures or "arbuscules" which are the site of phosphate exchange between fungus and plant. Vesicles, which contain lipids and are carbon storage structures, are formed commonly in most genera of Glomeromycota, although this will depend on environmental conditions (Smith and Read, 1997). GianinazziPearson (1996) pointed out that these obligatory biotrophs, the AM fungi, have a very broad host range, which makes them definitely different from the biotrophic fungal plant pathogens as well as other root symbionts.

Fossil records suggest that the AM symbiosis dates back to the Ordovician age, 460 million years ago (Redecker et al., 2000). These fossils indicate that Glomeromycota-like fungi may have played a critical role in facilitating the colonisation of land by plants. As AM fungi are obligate symbionts, they are not yet successfully cultured in the absence of plant root. The symbiosis is normally mutualistic and based on bi-directional nutrient transfer between the symbionts. However, the mycorrhizal association may vary along a symbiotic continuum from strong mutualism to antagonism (Carling and Brown, 1980; Modjo and Hendrix, 1986; Howeler et al., 1987; Johnson et al., 1997). More than 150 species are described within the phylum Glomeromycota on the basis of their spore development and morphology, although recent molecular analyses indicate that the definite number of AM taxa may be much higher (Daniell et al., 2001; Vandenkoornhuyse, et al., 2002). However, the biological knowledge is lacking for some of the described species and others are synonyms (Walker and Trappe, 1993; Walker and Vestberg, 1998). All members of the AM fungi are asexual and the vegetative mycelium and intraradical structures are aseptate and multinucleate. Most spores are between 50 and $500 \mu \mathrm{m}$ in diameter depending on the species.

Another type of mycorrhizal association is the ectomycorrhiza, in which the fungal hyphae form a mantle consisting of densely interwoven hyphae around the 
root. From this mantle external hyphae grow into the surrounding soil. Hyphae also grow inside the root forming the Hartig net in the spaces between epidermal and cortex cells. In addition, to the arbuscular- and ectomycorrhiza, the mycorrhizal associations can be classified into four other types based on the type of fungus involved and the range of resulting structures produced by the rootfungus combination (Table 1; Harley, 1959; Harley and Smith, 1983; Smith and Read, 1997; Read, 1998).

Table 1. The diagnostic structural features of the six recognised types of mycorrhiza (after Read, 2002)

\begin{tabular}{|c|c|c|c|c|}
\hline \multicolumn{2}{|l|}{ Mycorrhiza } & \multirow{2}{*}{ Fungi } & \multirow{2}{*}{ Plant } & \multirow{2}{*}{$\begin{array}{l}\text { Defining } \\
\text { structures }\end{array}$} \\
\hline Category & Type & & & \\
\hline \multirow[t]{3}{*}{ Sheathing $^{\mathrm{a}}$} & Arbutoid & $\begin{array}{l}\text { Ascomycetes } \\
\text { Basidiomycetes }\end{array}$ & $\begin{array}{l}\text { Arctostáphylos } \\
\text { Arbutus } \\
\text { Pýrola }\end{array}$ & $\begin{array}{l}\text { Hartig net and } \\
\text { intracellular } \\
\text { penetration }^{\mathrm{c}}\end{array}$ \\
\hline & Ecto & $\begin{array}{l}\text { Ascomycetes } \\
\text { Basidiomycetes }\end{array}$ & $\begin{array}{l}\text { Coniferous } \\
\text { and } \\
\text { broadleaved } \\
\text { forest trees }\end{array}$ & $\begin{array}{l}\text { Hartig net, } \\
\text { mantle, } \\
\text { external } \\
\text { mycelial } \\
\text { network }\end{array}$ \\
\hline & Monotropoid & $\begin{array}{l}\text { Basidiomycetes } \\
\text { (selected ecto fungi) }\end{array}$ & Monotropáceae & Fungal pegs \\
\hline \multirow[t]{3}{*}{ Endo $^{b}$} & Arbuscular & Glomeromycetes & Most families & $\begin{array}{l}\text { Arbuscules } \\
\text { Hyphal coils }\end{array}$ \\
\hline & Ericoid & $\begin{array}{l}\text { Ascomycetes } \\
\text { Hymenoscýphus } \\
\text { Oidiodendron }\end{array}$ & $\begin{array}{l}\text { Ericáceae } \\
\text { Epacridáceae } \\
\text { Empetráceae }\end{array}$ & $\begin{array}{l}\text { Hyphal } \\
\text { complexes } \\
\text { in hair roots }\end{array}$ \\
\hline & Orchid & $\begin{array}{l}\text { Basidiomycetes } \\
\text { Rhizoctonia } \\
\text { (some ecto fungi) }\end{array}$ & Orchidáceae & Peletons \\
\hline
\end{tabular}
proliferate internally, "also seen in the subtype "ectendo".

\section{Occurrence}

Members of more then $80 \%$ of extant vascular plant families are capable of forming the AM. In addition, AM fungi are widely distributed on the earth. They are reported from all continents; Africa (Redhead, 1977), Antarctica (Cabello, et al., 1994), Asia (Al-Garni and Daft, 1990; Ganesan et al., 1991), Oceanien (Hall, 1977), North America (Walker et al., 1982; Dalpé and Aiken, 1998), South America (Siqueira et al., 1989; Aguilera et al., 1998; Vestberg, 1999; Caproni et al., 2003) as well as Europe (Land and Schönbeck, 1991; Blaszkowski, 1993; Vestberg, 1995; Jansa et al., 2002). Arbuscular mycorrhizal fungi colonisation of plants have been observed over a wide range of soil pH (Read et al., 1976), soil phosphate levels (Crush, 1975; Hayman et al., 1976; Jeffries et al., 1988) and salinity (Gerdemann, 1968). There are, however, marked differences considering distribution and abundance among species and strains of AM fungi in response to soil properties. 


\section{Colonisation}

There are three important components of the mycorrhizal root system (Figure 1); the root itself, the intraradical mycelium (the fungi within the root) and the extraradical mycelium (the fungi within the soil). Colonisation of roots by AM fungi can arise from spores, infected root fragments and/or hyphae. The spores are formed on the extraradical hyphae, but some species also may form spores inside the roots. Soluble exudates or extracts from the roots of host species stimulate the

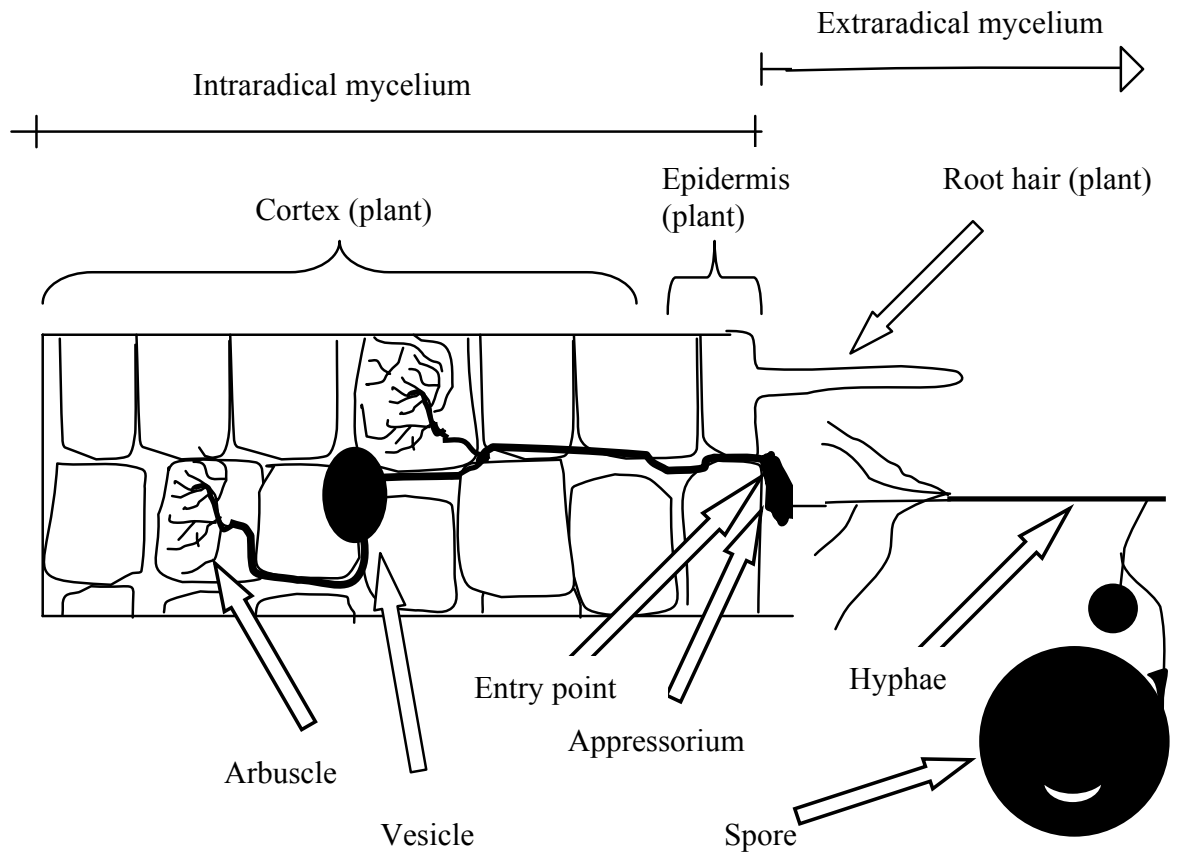

Figure 1. Simplified section of mycorrhizal root and external mycelium of arbuscular mycorrhizal fungi as seen on the microscope. The arrows point out the fungal structures.

growth and branching of mycelium growing from spores (Graham, 1982; Elias and Safir, 1987; Gianinazzi-Pearson et al., 1989), while the exudates from a nonhost had no effect (Gianinazzi-Pearson et al., 1989). The main hypha approaches a root often gives rise to a fan-shaped complex of lateral branches, which is thinner and may be septate, and colonisation of the root usually occur from these hyphae (Mosse and Hepper, 1975; Giovannetti et al., 1993a,b). Hyphal contact with the root is followed by adhesion and formation of swollen appressoria preceding the penetration (Bécard and Fortin, 1988; Giovannetti et al., 1993b). There is evidence that the host plant recognise the AM fungi already at this stage, which is indicated by regular occurrence of slight wall thickening on the epidermal cell adjacent to the penetrating hyphae (Garriock et al., 1989). The thickenings do not contain either callose or lignin and do not prevent the penetration of fungal hyphae through the walls (Harrison and Dixon, 1994). 
There are two types of mycorrhiza according to the structures of the intraradical mycelium; the Arum-type and the Paris-type (Gallaud, 1905). In the Arum-type the fungal symbiont spread in the root cortex via intercellular hyphae. Short sidebranches penetrates the cortex cells and produce arbuscules. The Arum-type is commonly described in fast growing root systems of crop plants. In the Paris-type the hyphae develop intracellular coils and spread directly from cell to cell within the cortex. Arbuscules grow from these coils. Co-occurrence of Arum- and Paristype morphologies of AM is found in cucumber and tomato (Kubota et al., 2005). Arbuscules are usually relatively short-lived, at least in the Arum-type mycorrhiza and the hyphae are comparable long-lived (Holley and Peterson, 1979; Smith and Dickson, 1991). The arbuscules progressively degenerate, whilst the plant cell remains alive, which is a difference compared to many plant pathogenic fungi which cause plant cell death. For rapidly growing crop species the formation of arbuscules may take 2-3 days and the whole arbuscular cycle approximately seven days (Bevege and Bowen, 1975; Brundrett et al., 1985).

The extraradical mycelium consists of two distinct types of hyphae, the runner hyphae and the absorbing hyphae (Friese and Allen, 1991). The runner hyphae are thicker and grow through the soil in search of roots. The hyphae that penetrate roots are initiated from runner hyphae. The absorbing hyphae also develop from the runner hyphae and form a network of thinner hyphae extending into the soil. These hyphae appear to be the component of the fungus that absorbs nutrient from the soil for transport to the host. Arbuscular mycorrhizal fungi can associate with multiple hosts, including different species (Hirrel and Gerdemann, 1979; Heap and Newman, 1980; Warner and Mosse, 1983; Read et al., 1985; Molina et al., 1992). Some mycorrhizal plants are thus probably interconnected by a common mycorrhizal network (Newman, 1988). This means, for example, that there is a movement of carbon from the root of one plant, through AM fungi, to roots of other plants (Francis and Read, 1984; Graves et al., 1997).

\section{Benefits for the AM symbionts}

As all mutualistic beneficial cooperations, both partners (fungi and plant) have advantages of the symbiosis. Carbon from the photosynthesis are used by the fungi and the plant make use of the extended soil volume. The AM fungi take up a significant fraction of all plant photosynthetically fixed carbon (Paul and Kucey, 1981). In a field study, between 3.9 and $6.2 \%$ of the fixed carbon are shown to be passed through the external mycelium of the AM fungal symbiont to the atmosphere (Johnson et al, 2002). The fungus acquires carbon as hexose within the root (Shachar-Hill et al., 1995; Solaiman and Saito, 1997), but it is stored primarily as triacylglycerol (Cox et al., 1975; Beilby and Kidby, 1980; Beilby, 1983; Jabaji-Hare, 1988; Gaspar et al., 1994), but also as glycogen (Bago et al., 2003). The net movement of storage lipid is from the intraradical mycelium to the extraradical mycelium, although there is also substantial recirculation throughout the fungus (Bago et al., 2002).

In return for the carbon, the mycorrhizal plant obtains nutrients such as, for example, inorganic phosphate via the AM fungal hyphae. The inorganic phosphate, as also other inorganic nutrients such as zinc, is relatively immobile in 
the soil solution, which leads to the formation of zones depleted in inorganic phosphorus around the roots. This depletion zones effectively limit phosphor uptake in non-mycorrhizal plants. The symbiotic association with AM fungi allows the plant to access phosphorus beyond the depletion zone through the extraradical fungal hyphae, in addition to the root uptake (Pearson and Jakobsen, 1993). Arbuscular mycorrhizal fungi also contribute to the uptake by plant of micronutrients, such as zinc (Thompson, 1990) and the macronutrient nitrogen, both inorganic and possibly also organic (George et al. 1995; Hawkins et al., 2000; Hodge et al., 2001). In addition to the nutrient uptake activity, the extraradical mycelium also releases substances that cause the soil and its organic components to aggregate (Sutton and Shepard, 1976; Tisdall and Oades, 1979; Tisdall, 1991; Tisdall, 1994; Bearden and Petersen, 2000). Another impact of AM fungi on the plants, including agricultural crops are their ability to increase their tolerance to drought (Davies et al., 1993) and reduce damage caused by plant pathogens (Dehne, 1982; Borowicz, 2001; Whipps, 2004). Hormonal changes throughout the entire plant under the influence of the symbiosis have also been described (Allen et al., 1980; Allen et al., 1982). Under some circumstances AM fungi are able to decrease negative effects by heavy metals in plants (Davies et al., 2001; Tonin et al., 2001; Rivera-Becerril et al., 2002).

\section{Agricultural impact on AM fungi}

Most of the cultivated plant species are able of forming the AM. However, the plant families Brassicaceae and Chenopodiaceae include species that do not usually form mycorrhizal symbiosis, among them sugar beet and rape (Tester et al., 1987). Growing these crops subsequently does not lead to any multiplying of AM fungi, unless there are weeds that can act as hosts (Abbot and Robson, 1991; Jansa et al., 2002). Mycorrhizal inoculum density also declines when soils are kept fallow for extensive periods of time (Black and Tinker, 1979; Thompson, 1987). The quantity of AM fungi in soils also differs between host species (Thompson, 1991; Vivekanandan and Fixen, 1991). Even the preceeding crop in a crop rotation system affect the AM fungal spore densities in the field and thereby the yield of the following crop (Thompson, 1991; Karasawa et al., 2001). Oehl et al. (2003) found that increased land use intensity was correlated with a decrease in AM fungal species richness and with a preferential selection of species that colonised roots slowly but formed spores rapidly. To remember is also that the most dominant species of AM fungi may not be the most beneficial mutualists. Johnson et al. (1992) showed that crop monocultures selected for AM fungi that were inferior mutualists. Thus AM fungi may be involved in the yield decline often observed in continuous monocultures. It has also been indicated that AM fungi from fertilised soil exert a higher net carbon cost on their host than AM fungi from unfertilised soil (Johnson, 1993). There is not only a difference between crop species in the degree to which they form mycorrhiza, there is also a difference between cultivars of the same species. Cultivars of wheat (Azcon and Ocampo, 1981; Young et al., 1985; Manske, 1990) and corn (Toth et al., 1984) have been shown to vary in levels of colonisation by AM fungi. In barley, an existing degree of host specificity is also indicated by Boyetchko and Tewari (1995) comparing yield and AM fungal colonisation of several barley cultivars 
inoculated with AM fungi. The degree to which cultivars are colonised by, and benefit from, mycorrhiza is a heritable trait selectable through plant breeding (Krishna et al., 1985; Kesava et al., 1990).

By returning crop residues to soil the farmer might stimulate an increased mycorrhizal infection and spore population, which is shown in tropical forage systems (Saif, 1986). Disturbances such as ploughing have shown to reduce the functioning of AM fungi (Kabir, et al., 1997; McGonigle and Miller, 1999). Furthermore, application of farmyard manure is shown to increase densities of AM fungal spores, although this depends on the soil types (Kruckelmann, 1975; Harinikumar and Bagyaraj, 1989). Several studies indicate that cumulative P fertilisation decrease the spore density under Northern European field conditions (Jensen and Jakobsen, 1980; Mårtensson and Carlgren, 1994; Kahiluoto et al., 2001). Furthermore, AM fungal colonisation are shown not to be affected by $P$ addition when plants are deficient in $\mathrm{N}$ but, when $\mathrm{N}$ was sufficient, $\mathrm{P}$ addition suppress root colonisation (Sylvia and Neal, 1990). Thus, there are cultivation measures available for the farmer to regulate the AM fungi at the field site. An important measure, apart from the choice of cropping systems, and cultivation is in conventional agriculture the use of fungicides. Systemic fungicides applied at field application rate are shown to reduce the functioning of the AM fungi (Menge et al., 1979; Kling and Jakobsen, 1997).

\section{Plant and AM fungal diversity}

The growth of many plant species is enhanced when AM fungi are present (McGonigle, 1988). It has also been shown in field and greenhouse experiments that AM fungi promote plant diversity in European grasslands (Grime et al., 1987; Gange et al., 1990, Gange et al., 1993; van der Heijden et al., 1998a). However, AM fungi can also reduce diversity, as has been observed in American tall grass praries (Hartnett and Wilson, 1999). The mycorrhizal dependency (or symbiotic effectiveness) of a plant shows the extent to which a plant benefits from the presence of AM fungi compared to when it is absent (Gerdemann, 1975; Plenchette et al., 1983; Johnson et al., 1997; van der Heijden et al., 1998b). Van der Heijden (2002) proposed that the number and relative abundance of mycorrhizal dependent plant species in the species pool of a community can be used to predict how AM fungi affect communities. Furthermore, recovery of disturbed ecosystems may depend upon the reestablishment of mycorrhizal fungi (Reeves et al., 1979; Janos, 1980; Allen and Allen, 1980; Perry et al., 1989).

However, not only the plants are affected by the AM fungi community, also the AM fungi respond to the plant diversity, as shown by comparing AM fungi community between plots cultivated with different number of plant species (Burrows and Pfleger, 2002). Species compositions of AM fungal communities also change during succession of abandoned arable fields (Johnson et al., 1991). When natural ecosystems are converted to agroecosystems the diversity of AM fungal communities tends to decrease, while diversity decreases as the intensity of agricultural inputs increases (Siqueira et al., 1989; Schenck et al., 1989; Sieverding, 1990). Since the species composition of AM fungal communities are influenced by plant species (Dodd et al., 1990; Johnson et al., 1991) this could be 
an evidence of specificity between plants and AM fungi. Klironomos (2003) found a variation in response of different plant species to both different AM fungi coexisting with the plant in the nature and to AM fungi with an other origin than the plants. Since isolates of AM fungi differ in their effect on plants, Johnson and Pfleger (1992) stressed that highly diverse community of AM fungi may be desirable to increase possible options for host-fungus combination. On the contrary, less diverse AM fungal communities may be superior if the few fungal species that are present are good mutualists (Sieverding, 1990).

\section{Bipolaris sorokiniana}

\section{Taxonomy}

Bipolaris sorokiniana (Sacc. in Sorok.) Shoem. is a widespread fungus which can cause disease in barley, wheat and rice but also other grasses and infrequently other taxonomic groups (Wildermuth and MacNamara, 1987). An earlier name for the fungus was Helminthosporium sativum (Pamm. King and Blake), but the genus Helminthosporium has now been divided into Drechslera and Bipolaris (Alcorn, 1988). The sexual stage (telemorph) of B. sorokiniana is Cochliobolus sativus (Ito and Kurib.). The sexual stage is mainly known from laboratory cultures, but is also reported from the field in Zambia (Raemaekers, 1991). Another name used for the asexual stage in the literature is Drechslera sorokiniana ((Sacc.) Subram. and Jain). The conidia are curved to straight, fusiform, to broadly ellipsoidal and germinate by one germ tube from each end (bipolar germination). The size of the conidia is 40-120 x 17-28 $\mu \mathrm{m}$ and they have 3-12 distoseptates (Figure 2) (Sivanesan and Holliday, 1981). The conidia are able to germinate using endogenous energy reserves, but are stimulated by exogenous nutrients such as root exudates (Nilsson et al., 1993). Fungal infection of both leaves and roots comprises several phases: conidia germination, formation of appressoria, penetration, and colonisation (Yadav, 1981; Carlson et al., 1991). Bipolaris sorokiniana produces toxins which interact with host membranes resulting in cell death and leakage of metabolites (Marrè, 1980; Harborne, 1983). The phytotoxins induce both chlorosis and necrosis in plant tissue (Harborne, 1983). Carlson et al. (1991) found that the most active and abundant phytotoxin formed was prehelminthosporol $\left(\mathrm{C}_{15} \mathrm{H}_{24} \mathrm{O}_{2}\right)$. They found the toxin in conidia, hyphae and the surrounding culture medium.

\section{Diseases and dispersal}

Depending on the site of infection B. sorokiniana can cause different diseases like common root rot, spot blotch, seedling blight, foot rot and crown rot of wheat and barley (Lee, 1986). The diseases are increasingly important in barley in the cool climate of North-Western Europe (Jørgensen, 1974; Kurppa, 1984). Yield loss of up to $15 \%$ are reported (Piening, 1973; Olofsson, 1976; Stack, 1982; Kurppa, 1985; Forsberg, 2004). Earlier they were considered mainly as serious diseases of warmer cereal growing regions, chiefly North America, and parts of Australia and New Zealand (Sivanesan and Holliday, 1981). Severe yield losses, up to $100 \%$, due to B. sorokiniana occur in Bangladesh, Bolivia, Brazil, Paraguay and Zambia (Mehta, 1997). 
Also from South and Southeast Asia the diseases caused by B. sorokiniana are reported (Saari, 1997). Of the fungal pathogens of cereal crops in

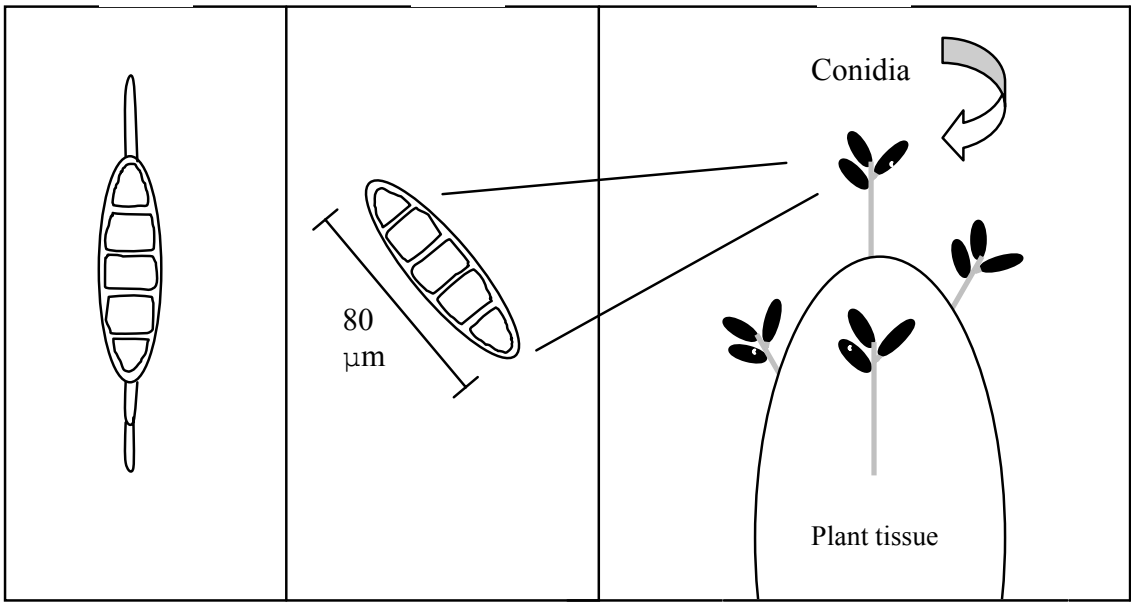

Figure 2. Bipolaris sorokiniana with; a) bipolar germination of the conidia, b) conidia with five distoseptates as seen on the microscope, c) black shiny conidia as seen on the binocular microscope.

Hungary, Bipolaris species have increased in importance (Bakonyi et al., 1998). Greenhouse experiments have shown that the pathogen can develop and induce the formation of leaf spots at as low temperatures as $6^{\circ} \mathrm{C}$ (Dehne and Oerke, 1985). Symptom development, were intensified at temperatures higher than $20^{\circ} \mathrm{C}$, high relative humidities $(>30 \%)$ and elevated light intensities $(>3000 \mathrm{~lx})$. However, incubation under temporary low light conditions accelerated senescence of leaves in a short time (Dehne and Oerke, 1985).

Bipolaris sorokiniana is seed-borne causing primary infection, soil-borne or disseminated by air currents that carry them as inert particles to various distances and cause secondary infections (Figure 3 ). In the soil the conidia are able to remain their infectivity capacity for at least 22 months (von Ammon, 1963) and may infect the following crop. Infection can take place through stomata on the hypocotyls, from where the fungus progress to the root, shoot and coleoptile (Sprague, 1950). Dark brown, lenticular spots of variable size form on the young leaf sheaths; post emergence death may occur. Roots show brown spotting or a more general necrosis. Conditions for the occurrence of secondary infection of barley are most favourable during the late growing season, when crops are nearly ripe and relative humidity is high for at least part of the day (Spurr and Kiesling, 1961). Air-borne secondary infection may result in necrotic spots on the leaf as well as infection in ripening seeds (Mead, 1942; Vendrig, 1956). The fungus may also spread symptomless on the plant and yield losses may even occur without severe disease symptoms (Kurppa, 1985). 


\section{Control measures}

Bearing in mind the dispersal strategies of $B$. sorokiniana measures to control the diseases could be by I) avoiding the production of conidia, II) their ability to survive and infect in the soil, III) their ability to develop from seed-infections or IV) their ability to infect the green parts of the plant through the spread in the air. This could be done by a mixture of $B$. sorokiniana suppressing cultural practices. Kurppa (1985) found, while studying the soil-borne B. sorokiniana, that the inoculum density of the soil was of major importance, in terms of decreasing the growth of the barley plants, compared to fungal isolates or barley cultivars. The longer the time interval between susceptible hosts, the lower the ratings of common root rot (Ledingham, 1961). In crop rotations design to reduce the soilinoculum density of B. sorokiniana low sporulation on oilseed rape and red clover indicates their suitability in the rotation (Duczek et al., 1996). Bailey et al. (1992) found that inoculum levels and isolation frequencies of B. sorokiniana in wheat was reduced by reduced tillage, wheres Reis (1990) found that no tillage favored inoculum production by common root rot because large numbers of conidia were produced on host residues left on the soil surface. There are significant differences in the reactions of barley cultivars to the fungus, but no complete resistance has been shown (Duczek, 1984; Kurppa, 1985). Considering chemical treatments, the postemergence herbicides 2,4-D, MCPP and dicamba are shown to increase $B$. sorokiniana disease severity on Poa pratensis, a host plant resistant to the herbicides in the studies (Hodges, 1978, 1984). Different herbicides also increase the sporulation of $B$. sorokiniana on P. pratensis leaf tissue of all ages (Hodges, 1992, 1994), which could influence inoculum potential of the soil and disease severity of a following barley crop.

Considering the seed-borne diseases, hot humid air treatments of the seeds are shown to reduce the yield loss due to B. sorokiniana (Forsberg, 2004), but are not commercialised. Seed treatments based on the bacteria Pseudomonas chlororaphis (Cedomon ${ }^{\circledR}$ ) against the pathogens caused by Drechslera sp., is available but has uncertain effects against $B$. sorokininana (Bioagri, Sweden; Olvång, 2002). The seed-borne disease in conventional farming is usually controlled through the use of chemical seed treatment (Sivanesan and Holliday, 1981). The infections from soil-borne inoculum, including inoculum on plant debris are difficult to control by chemical seed treatments. The extent of pathogens may even increase as a result of the treatment of seeds with fungicides (Daamen, et al., 1988, 1989). It is possible that this increase is caused by the elimination of antagonistic organisms (AlHashimi and Perry, 1986). Knudsen et al. (1995) found that isolates of the fungi Idriella bolleyi, Chaetomium sp., and Gliocladium roseum inoculated on barley seeds acted as antagonists towards B. sorokiniana. In a six years field study, treatment of barley seed with Idriella bolleyi decreased the disease symptoms caused by B. sorokiniana by $16 \%$ and led to an average yield increase of $4 \%$ (Duczek, 1997). Furthermore, I. bolleyi inoculated on barley seeds are shown to cause systemic induced resistance on the plants to subsequent infection with $B$. sorokiniana (Liljeroth and Bryngelson, 2002). Also bacteria have shown to reduce infection frequency of $B$. sorokiniana (Zhang and Yuen, 1999). 


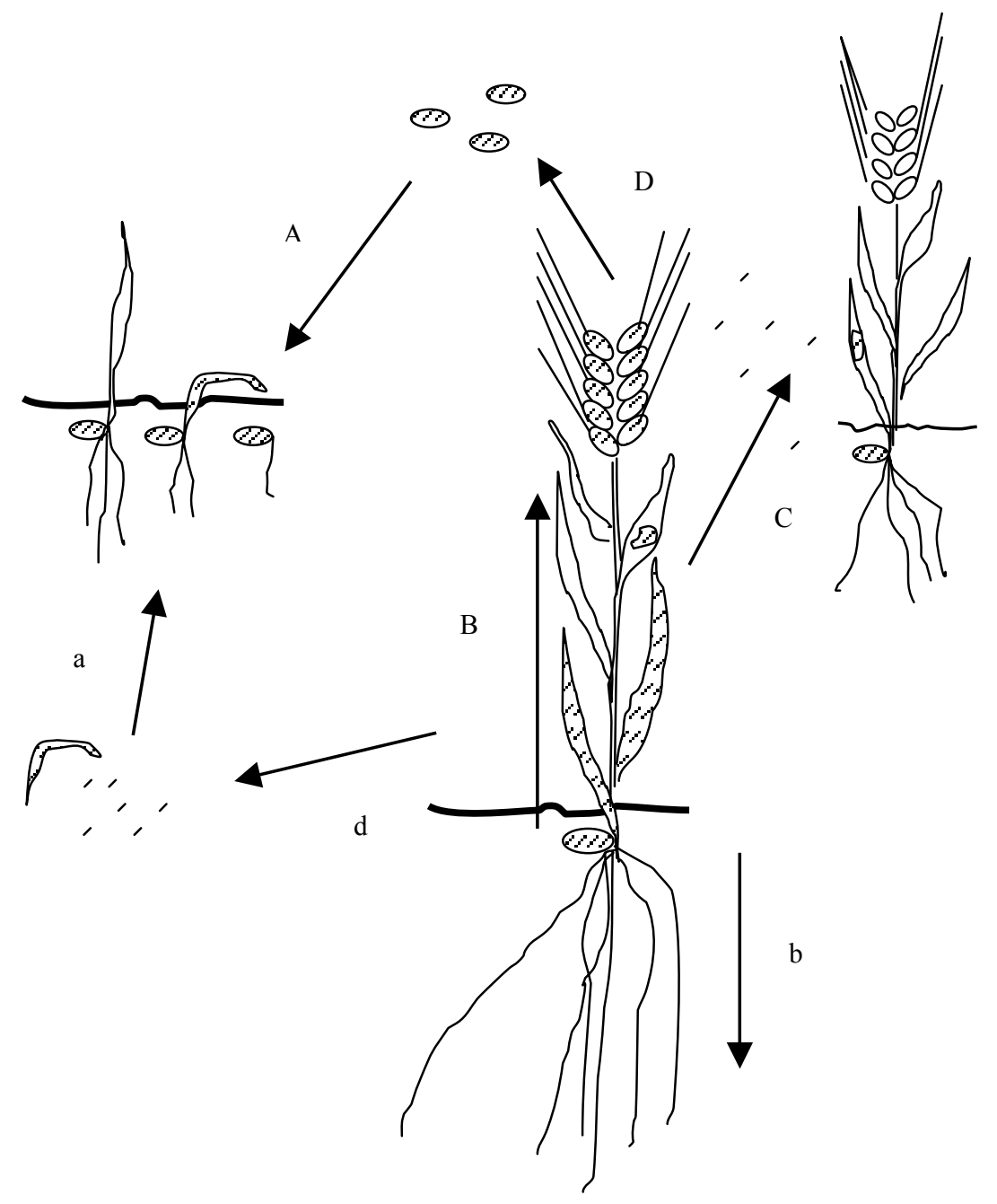

Figure 3. Disease cycle. Primary infection of a barley plant by overwintering Bipolaris sorokiniana in seed (A), or in the soil, either as conidia or as saprophytes on plant debris (a). The pathogen develop in the surviving plants with or without symptoms in the aerial plant parts (B) and to the roots (b). The conidia produced during the season may spread to different parts of other barley plants $(\mathrm{C})$ or to weeds and cause a secondary infection. Finally, the pathogen survive to the next growing season in the seed (D) or in the soil (d). 
In Australian fields, a decline in propagules of AM fungi during weed free fallow caused delayed root colonisation and poor growth of the next crop (Thompson, 1987). In proceeding studies Thompson and Wildermuth (1989) found that AM fungal colonisation of crop and pasture species was negatively correlated with root infection by B. sorokiniana. This indicates that AM fungi antagonise root infection by $B$. sorokiniana. However, they did not find a correlation between AM fungal colonisation and infection of stem bases with $B$. sorokiniana. Dehn and Dehne (1986) found a lower C. sativus (B. sorokiniana) infection of root tissue if the roots were already colonised by AM fungi.

\section{AM fungi in disease control}

The role of AM fungi in disease control have been studied in a number of plant pathogen - host species combinations. Borowicz (2001) showed that AM fungi reduced the detrimental effects of pathogens that extended beyond additive effects resulting from improved nutrition. This conclusion was made using a biometrically based examination (meta-analysis) of plant growth based on 22 papers considering the effects of AM fungi on plant-pathogen interactions. For effective control, inoculation of the AM fungus should generally take place prior to exposure to the pathogen, although there are a few exceptions known (Caron et al., 1986; StArnaud et al., 1997). Several AM fungal species have been found to control soilborne pathogens, for example under greenhouse conditions Glomus fasciculatum and Gigaspora margarita are shown to decrease root rot diseases caused by Fusarium oxysporum f. sp. asparagi and Helicobasidium mompa in asparagus (Asparagus officinalis L.) (Matsubara et al., 2000; Matsubara et al., 2001) and Glomus clarum is shown to decrease root necroses due to Rhizoctonia solani in cowpea (Vigna unguiculata L.) (Abdel-Fattah and Shabana, 2002). In pasteurised soil AM fungi have shown to decrease the root damage caused by the root-rot fungus Cylindrocladium spathiphylli in bananas, although the pathogen decreased the intensity of AM fungal root colonisation (Declerck, et al., 2002). Newsham et al. (1994) found that AM fungi interact directly with root pathogens of the winter annual grass Vulpia ciliata, and improved fecundity by interfering with the negative effects of the pathogens. Results from the same study showed that the main benefit supplied by AM fungi to the plant was in protection from pathogen attack, not in phosphorus uptake. Considering foliar pathogens reports indicate that those are sometimes stimulated by AM symbioses (Meyer and Dehne, 1986; Shaul et al., 1999). However there are indications that foliar disease symptoms caused by a phytoplasma in tomato are reduced (Lingua et al., 2002). Studies have shown that some AM fungal colonisation also can increase disease incidence caused by soil-borne pathogens (Ross, 1972; Davis et al., 1978; Davis and Menge, 1980). Working with potato and Rhizoctonia solani, Mark and Cassells (1996) showed that different levels of control of the pathogen could sometimes be found with the same AM fungus on different cultivars of plants.

\section{Mode of actions in biocontrol with bearing to B. sorokiniana and AM fungi}

Competition for nutrients and space occur between pathogens and other microorganisms (Wilson and Wisniewski, 1989; Wisniewski et al., 1989; Roberts, 1990; Mercier and Wilson, 1994). The importance of nutrients were also showed by 
Droby et al. (1989), where an addition of exogenous nutrients to the interaction site resulted in decreased efficacy of the antagonist. With the knowledge of the nutrient flows in AM fungi it could be speculated that these fungi therefore are promising candidates for use in biocontrol. The extent to which the nutrient competition reduces infection may vary with the infection strategy of the pathogen involved. Fokkema (1971) found that the presence of pollen, highly stimulated the spore germination and the superficial growth of mycelium of the pathogen Cochliobolus sativus infection on rye leaves. This resulted in more penetration sites and an increase in necrotrophic leaf area. There was a positive correlation between the superficial mycelium density of $C$. sativus 2-3 days after inoculation and the necrotrophic leaf area. The presence of phyllosphere yeasts reduced the enhanced mycelium density and subsequent necrosis (Fokkema, 1973). Considering the competition for iron an advantage is the possible production of siderophores. Siderophores is a metabolic product which binds iron and facilitates its transport from the environment into the microbial cell. Fluorescent Pseudomonas spp. produces siderophores and are very efficient competitors for iron (Bakker et al., 1990), and competition for iron is one of the mechanisms responsible for soil suppressiveness to fusarium wilts (Scher and Baker, 1982; Lemanceau et al., 1988). There is some evidence that AM fungi may produce siderophores. The AM grass Hilaria jamesii, which showed greater iron uptake than a non-mycorrhizal control, tested positive for siderophores when bioassayed (Cress et al., 1986). Arbuscular mycorrhizal fungi are shown to suppress the plant diseases due to increased uptake of macro- and micronutrients or drought tolerance of the AM fungal plant. Alleviation of abiotic stress, such as decreased toxicity to salt and heavy metals by AM fungal colonised plants have shown to decrease disease in some cases (Hooker et al., 1994; Linderman, 1994; Karagiannidis et al., 2002). Altered root branching or root morphology due to AM fungal colonisation may also decrease the negative effect of plant pathogens (Norman et al., 1996; Fusconi et al., 1999). Between AM fungi and the pathogen there might also be a competition for energy derived from the photosynthesis of the host. This has been shown by Larsen and Bødker (2001) studying Aphanomyces euteiches in pea (Pisum sativum) the biomass of both the pathogen and the AM fungi decreased. The reduced AM fungal biomass can alter the microorganisms surrounding the root (Hodge, 2000; Mansfeld-Giese et al., 2002), which might include bacteria antagonistic to plant pathogens (Andrade et al., 1997; Andrade et al., 1998; Citernesi et al., 1996).

Not only the rhizosphere, but also the mycorrhizosphere might favour the growth of micro-organisms antagonistic to plant pathogens (Filion et al., 1999; Norman and Hooker, 2000; Filion, et al., 2003). Soil micro-organisms influence AM fungal development and symbiosis establishment. Negative impacts include a reduction in spore germination and hyphal length in the extraradical stage, decreased root colonisation and a decline in the metabolic activity of the internal mycelium (Wyss et al., 1992; McAllister et al., 1995). There are also positive effects found; Azcon-Aguilar and Barea (1985) observed that colonisation of a plant by an AM fungus (G. mosseae) was stimulated by a strain of Pseudomonas sp. Gryndler and Vosatka (1996) found that Pseudomonas putida stimulated maize root colonisation by Glomus fistulosum, and that the dual inoculation had a 
synergistic effect on plant growth. Similar results are observed in other studies (Azcon-Aguilar et al., 1986; Azcon, 1987; Linderman and Paulitz, 1990).

A nearly omnipresent feature of plant-pathogen interactions is host cell death. In some cases the cell death occur as rapid collapse of tissue, termed the hypersensitive response (HR). This response accompanies "incompatible interactions" and leads to disease resistance. The HR is programmed genetically in the plant and is a consequence of new host transcription and translation (Dixon et al., 1994; Godiard et al., 1994). A local HR is often associated with the onset of systemic acquired resistance (SAR; Chester, 1933; Enyedi et al., 1992; Ryals et al., 1994, 1996) in distal plant tissue. Some plant responses are very quickly, within hours, after the induction event (Zangerl and Berenbaum, 1995). However, some examples of SAR occur without this HR (Jakobek and Lindgren, 1993; van Loon et al., 1998). Furthermore, HR cell death is not always required to stop pathogen growth (Century et al., 1995; Hammond-Kosack et al., 1996). The SAR may also be triggered without plant cell death. On the contrary, necroses are equally a feature of disease symptoms during compatible interactions. The cells are often killed via the action of pathogen-derived toxins, which is one feature of B. sorokiniana (Marrè, 1980; Harborne, 1983). Necroses induced by compatible pathogens do induce SAR (Jenns and Kuc, 1977; Cohen and Kuc, 1981; Kuc, 1987). Plant control the ingress of potential fungal pathogens with increased activity of enzymes and accumulations of cell-wall proteins associated with defence. The enzymes that may accumulate is, for example, those which are involved in enhanced phenolic metabolism (Ryder et al., 1987), or the degrading of fungal cell walls (Hedrick et al. 1988; Edington et al., 1991). Enhanced accumulations of structural protein may increase the resistance of plant cell walls to enzymatic degradation by a potential pathogen (Cordier et al., 1998).

Plant defence-like responses to AM formation have been reported in several mycorrhizal systems during the initial stages of AM fungal colonisation (Spanu and Bonfante-Fasolo, 1988; Spanu et al., 1989). At later stages, the defence-like responses in AM fungal colonised roots dropped below levels in the controls with no added AM fungi. However, in other studies the accumulated plant-defence like responses remained at later stages (Harrison and Dixon, 1993, 1994; Blee and Anderson, 1996). Systemic suppression of AM fungi colonisation of barley roots already colonised by AM fungi has been indicated (Vierheilig et al., 2000).

\section{Material and methods}

The experimental set-ups used in the studies are summarised in Table 2, presenting which important factors considering barley - AM fungi - B. sorokiniana interactions that were included.

\section{Indigenous AM fungal spores}

To investigate the occurrence of AM fungi in Sweden, sampling sites were chosen on a broad range of arable fields in the country, in total 45 different sites (Paper I). 
Table 2. Experimental set-ups

\begin{tabular}{|c|c|c|c|c|c|}
\hline \multirow[t]{2}{*}{ Factors studied } & \multirow[t]{2}{*}{ System } & \multirow[t]{2}{*}{ Design } & \multicolumn{3}{|c|}{ Paper } \\
\hline & & & $\mathrm{I}$ & II & III \\
\hline Occurrence of AM fungi & Field sites & Field soil & $\sqrt{ }$ & & \\
\hline Transmission of $B$. sorokiniana & Non-sterile soil & Pots $^{\mathrm{a}}$ & & $\sqrt{ }$ & \\
\hline Spot development on barley leafs & Gnotobiotic $^{\mathrm{b}}$ & Bottles $^{c}$ & & & $\sqrt{ }$ \\
\hline Growth of barley plants & Non-sterile soil & Pots $^{\mathrm{a}}$ & & $\sqrt{ }$ & \\
\hline AM fungi root colonisation & Non-sterile soil & Pots $^{\mathrm{a}}$ & & $\sqrt{ }$ & \\
\hline -"- & Gnotobiotic $^{\mathrm{b}}$ & Bottles $^{c}$ & & & $\sqrt{ }$ \\
\hline AM fungal spore germination & In vitro & Petri dishes & & & $\sqrt{ }$ \\
\hline B. sorokiniana conidia germination & In vitro & Petri dishes & & & $\sqrt{ }$ \\
\hline
\end{tabular}

${ }^{a}$ In greenhouse $;{ }^{b}$ Gnotobiotic = growth conditions in which all the living organisms are known;

${ }^{c}$ In climate chamber.

The sites included both semi-natural grassland and ploughed fields. The localities were situated between $55.4^{\circ}$ and $65.4^{\circ}$ North and between $13.2^{\circ}$ and $21.2^{\circ}$ West. The highest altitude was 707 meter above sea level. The samples were taken with a soil drill that was pushed down to $30 \mathrm{~cm}$ in the soil profiles. The soil cores were divided in two halves for comparison of the amount of AM fungal spores at different depths. All soil samples were analysed for their AM fungi spore content, by modification of the methods for wet sieving (Gerdemann and Nicolson, 1963) and centrifugation (Walker et al., 1982). The spore suspensions were then vacuum-filtered and the spores were counted on the filter papers under a compound microscope. The spores of a subset of the samples were mounted on microscope slides (Schenck and Péres, 1990) and identified to the level of genus or species. The samples chosen for determination of AM fungal diversity represented different agro-climatic zones and crops at the sampling time. All soils were also analysed for content of clay, phosphorus, nitrogen and carbon.

\section{Greenhouse experiments}

To get enough AM fungi for the greenhouse experiments the AM fungal populations from the field soils (Paper I) were multiplied in greenhouse using a mixture of plant species (Alexandrian clover, corn, leek, marigold, pea, sunflower, tomato, wheat and white clover), i.e. trap cultures. The mixture of plant species in the trap cultures did not include barley, to avoid multiplying possibly barley pathogens. Cores of field soil were placed onto trays containing a sand/silt mixture. Each tray represented a particular field. At maturity, plants were harvested and new seeds were sown. All experiments include controls with no added AM fungi. Information about the origin of the field soil used in the trap cultures are seen in Papers I and II. Each trap culture have a reference number, the same number are used in text and Tables.

A first screening survey was conducted with an aim to select for studies the most promising AM fungal populations with respect to their potential for reducing infection by B. sorokiniana in barley plants (Paper II). Soil inocula from eight different AM fungal trap cultures were chosen for the screening survey. The inocula were collected after the first generation of trap plants. Barley kernels with seed-borne $B$. sorokiniana were sawn in pots and soil inocula from the AM fungal 
trap cultures were added. Since the AM fungal populations were added as soil inocula this made it possible to include all existing AM fungal species whether they had sporulated or not at the time for inocula collection in the trap cultures. At harvest the number of living plants in each pot was noted, as well as the height of the plants. The stem bases were cut and incubated in a moist chamber for analysis of B. sorokiniana.

In a second experiment with soil inocula from the AM fungal trap cultures in the greenhouse (Paper II), AM fungal trap cultures from two different origins were selected from the screening survey above. The inocula were collected from the trap cultures after the second generation of the plants. In addition a commercial inoculum was included (Vaminoc $\AA$, Becker Underwood, MicroBio) all three combined with three levels of $B$. sorokiniana seed infections (54\%, 72\%, 95\%). Two controls were set up, lacking AM fungi; Control 1 (based on a substrate treated in the same way as the AM fungal trap cultures, but with no added AM fungi), Control 2 (a sand/silt mixture, with no added AM fungal inoculum). Barley kernels with seed-borne $B$. sorokiniana were sawn in pots. The plants were placed in the greenhouse. At harvest the number of living plants in each pot was noted, as well as the height of the plants. The stem bases, nodes and leaf spots were placed in a humid chamber for analysis of $B$. sorokiniana.

To avoid interference from other possible soil microorganisms an experiment was conducted with AM fungi added as spore mixtures (Paper II) from the AM fungal trap cultures. Arbuscular mycorrhiza fungi from one trap culture used in both previous experiments were chosen for the third greenhouse experiment. The spores were collected after the third generation of the trap plants. In addition AM fungi from eight other trap cultures with Swedish origins (Paper I) were chosen together with one commercial inoculum with in vitro cultured, surface sterile $G$. intraradices (see Paper II). The B. sorokiniana infected barley seeds were pregerminated. The spores were added to the roots of the seedlings in small plastic trays to allow close contact between the AM fungi and the roots. The plastic trays with seedlings were transferred to pots and the plants were grown in greenhouse. At harvest root pieces, stem bases, stem and leaf parts at the base of each leaf and leaves were placed in a humid chamber for analysis of B. sorokiniana. For AM fungi colonisation studies, the roots were cold-stained (after Koske and Gemma, 1989; Grace and Stribley, 1991; Walker and Vestberg, 1994). This was found to be a more gentle method for the root rot affected roots compared to hot staining. The roots were spread onto Petri dishes and the AM fungi colonisation were observed under a binocular microscope and estimated as percentage of roots colonised. The amounts of necroses due to the pathogen were also recorded. Low levels of nutrients were maintained during the plant growth experiments.

\section{In vitro studies}

The mechanisms involved in the interactions between B. sorokiniana and AM fungi were studied in a series of experiments under sterile conditions (for details see Paper III). A technique was developed for studying the effect of AM fungi on disease development of pathogens on the host plant under gnotobiotic conditions. 
The AM fungal species used in the experiments were $G$. intraradices and $G$. proliferum. The media used were $0.2 \% \mathrm{M}$ medium (w/v. Bécard and Fortin, 1988), PDA (potato dextrose agar, Oxoid Ltd, $39 \mathrm{~g}$ per litre) and $1 \%$ water agar. In all experiments controls lacking the parameter (fungi, exudates filtrates) were included.

The direct interactions between B. sorokiniana and AM fungi where studied by co-culturing on the same medium. The effect of possible volatile compounds produced by either $B$. sorokiniana or $G$. intraradices was studied by culturing the two organisms on one Petri dish devided from each other by a plastic slide. Effect of exudate filtrates of $B$. sorokiniana on AM fungi were studied. The exudate filtrates were spread on top of $\mathrm{M}$ medium before the AM fungal spores were added. Extract of $G$. intraradices hyphae grown on transgenic carrot roots (separated from the roots with a plastic slide) was also obtained and the effect on conidia germination of $B$. sorokiniana was studied. The effects were observed by colony-diameter of $B$. sorokininana, spore- or conidia germinations and hyphal growth of germinated AM fungal spores.

Since the AM fungi are obligate symbionts it has not been possible to grow these fungi in vitro until relatively resently. Mosse and Hepper (1975) reported the use of root organ culture to obtain typical infections with Glomus mosseae in vitro and Mugnier and Mosse (1987) have developed a method using Ri T-DNA transformed roots. The methods were developed further by Bécard and Fortin (1988). Since then several interaction studies have been conducted in vitro between AM fungi and the transgenic roots. In present work, a method was developed for studying the effect of an established AM fungi colonisation in nontransgenic barley roots on the disease development of B. sorokiniana infected leaves in vitro (for details see Paper III). Pieces of transgenic carrot roots colonised with $G$. intraradices were inoculated in bottles with $\mathrm{M}$ medium. The AM fungi were allowed to develop a network of hyphae in the medium for six months, since a living hyphal network is important in initiating rapid colonisation in seedlings (Read, et al., 1985; Read, 1992), before the seedlings were inserted. The result was a rapid colonisation of the barley roots of AM fungi. Seeds of barley were surface sterilised (after Åström, 1990) and pre-germinated. The seedlings were placed in one bottle each and covered with a layer of Vermiculite (Askania, Göteborg, Sweden). A figure describing the experimental set-up is seen in Paper III; Figure 1. The bottles were placed in a growing chamber, after one week plugs of $B$. sorokiniana grown on water agar were inoculated on the barley leaves. When the lesions (necroses developed as a symptom of the disease initiated by B. sorokiniana) started to develope their lengths were measured each day. The roots were cold-stained (after Koske and Gemma, 1989; Grace and Stribley, 1991; Walker and Vestberg, 1994) and the AM fungal colonisation was studied under binocular microscope. 


\section{Results and Discussion}

The plant pathogenic fungus $B$. sorokiniana has the capacity to infect the host directly on the leaf, while air-borne, on the roots, while soil-borne or through the seed, while seed-borne. It is therefore important to consider the diverse infection strategies if aiming to develop tools for biocontrol. While earlier workers have shown that AM fungi are able to suppress the B. sorokiniana in the roots, there was a lack of information concerning the interaction in the aerial parts of the plants. Reports on foliar diseases have indicated that the pathogens are enhanced by AM fungi (Whipps, 2004). Is this the case also for the development of $B$. sorokiniana from seed infection to the aerial plant parts? It could also be suggested that there is a difference between isolates of AM fungi in their possible ability to suppress the pathogenic fungus in aerial plant parts. Having found out that several multiplied field populations of AM fungi suppress the B. sorokiniana in stems and leaves, even through the pathogen had an advantage in that it was seed-borne and having seen that the pathogen was suppressed although the AM fungal colonisation was low I wondered how do these two fungi interact within the soil? Being such a successful pathogen, B. sorokiniana might have a competition advantage in the soil against the commonly occuring AM fungi. Lastly, I wondered how does the AM fungi affect the air-borne $B$. sorokiniana infecting the host leaves and how is it possible to study this without any influence of other organisms?

\section{AM fungi occurrence}

As it was hypothesised, AM fungi differs in characters depending on their origin; and since there was only scarce data on AM fungi in Sweden (Mårtensson and Carlgren, 1994; Eriksson, 2001; Hedlund, 2002) a first step was to make a survey of AM fungi under various prevailing climatic/cultivation conditions. The idea was to cover the broad spectrum of commonly occurring agroecosystems in Sweden. Therefore, sampling sites were chosen in different agro-climatic zones, based on both climatic and soil properties (Carling and Joner, 1998). In each zone samples were taken from both ploughed and unploughed arable fields, i.e. seminatural grasslands. The ploughed fields chosen were cultivated using agricultural practices common for each area.

Arbuscular mycorrhizal fungi were found to be present at all sampling sites in this study. This shows that the AM fungi and its symbiosis with plants are widely spread in agricultural fields in Sweden. Arbuscular mycorrhizal fungi have also been found in other Northern areas, although not to the same extent as reported in Paper I. Vestberg (1995) found AM fungi spores in half of the 266 indigenous soil samples taken from different parts of Finland (61-68 North). However, the presence of AM fungi were detected after multiplication on trap plants, thus there might have been AM fungi present in a higher proportion of the indigenous samples, although they did not form spores in the trap cultures. At even higher latitudes $\left(74-80^{\circ}\right.$ North) in the Arctic, AM fungal spores have been found in the indigenous soil of 9 out of 13 collected sites, at densities between 1-3 spores per $g$ 
soil (Dalpé and Aiken, 1998). They took the soil samples from the rhizosphere of Festuca species growing in the tundra. At the sampling location in Sweden with the highest latitude $\left(65.4^{\circ}\right.$ North), Hindersön situated on an island in the Baltic Sea, the spore densities was as high as 21 spores per g dry soil (Paper 1; Table 1-2). Overall the spore densities found ranged between 3-44 spore per g dry weight of soil in this study. The lowest spore density was found in a cereal monoculture, and the highest spore density in a semi-natural grassland. There were significantly more AM fungal spores in the upper half than in the lower half of the top $30 \mathrm{~cm}$ of the soil profiles. This relationship was not affected by ploughing. Other studies also show a decline in spore densities down the soil profiles (Jakobsen and Nielsen, 1983; Abbot and Robson, 1991). Multivariate statistics in terms of Principal Component Analysis did not show any groupings of the spore densities according to physical analysis, crop or agroclimatic zones of the sampling sites.

\section{Diversity and symbiotic effectiveness}

Between three and seven AM fungal spore types were found at the eight sampling localities in which spores were identified (Paper I). Most species belonged to Glomus spp., but species within Scutellospora were also found. The two samples with highest number of spore types originated from the two semi-natural grasslands, with high plant diversities, no ploughing and no addition of fertilisers. The six samples with lower number of spore types originated from more intensively managed ploughed fields, with low plant diversities. However, there may probably be more AM fungal species present, since all species might not have sporulated at the sampling time (Miller et al., 1985). For example, Glomus mosseae was not found in the indigenous soil samples, although this is a common species found in temperate climate (Vestberg, 1995). However, spores of Glomus mosseae type (Figure 4) were found in one of the AM fungal trap cultures of indigenous soils (Paper I, Table 2; trap culture no 43).

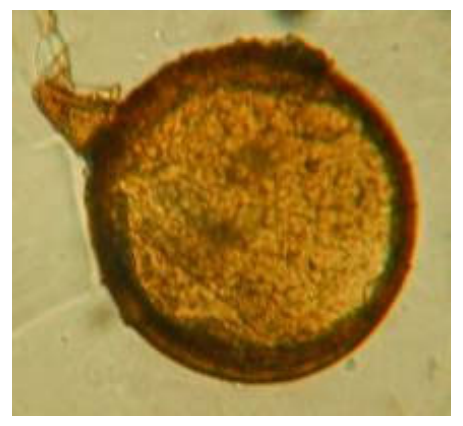

Figure 4. Arbuscular mycorrhizal fungal spores in close resemblance with Glomus mosseae.

Burrows and Pfleger (2002) also found more AM fungal species at higher plant diversity. Jansa et al. (2002) found that the community structure of AM fungi in the field soil was affected by tillage treatment, but there were no difference in AM fungal diversity. In an Indonesian study soil disturbance reduced the density of spores, species richness and the lengths of extra-radical mycelium of AM fungi 
(Boddington and Dodd, 2000). Also in temperate zones the hyphal density of AM fungi is shown to be reduced by ploughing (Kabir et al., 1998). Soil disturbance clearly affect the AM fungi. By ploughing the soil almost every year, the AM fungal species that dominate is probable adapted to disturbance (Oehl et al., 2003). This adaptation may in turn affect the quality of the AM fungal communities. Consequently, it might be possible to improve the mutualistic value (symbiotic effectiveness) of the AM fungal communities by adjusting the agricultural practises. Boddington and Dodd (2000 a, b) showed that AM fungi from different genera respond differently not only to disturbance but also to addition of phosphate fertiliser. As noted by Janos (1993) symbiotic effectiveness depends on the interactions between "mycorrhizal plant $\times$ mycorrhizal fungus $\times$ soil characteristics".

Both the plant and the soil characteristics are possible to adjust by agricultural practices and thereby the effectiveness of the indigenous AM fungi. Plenchette (1983) defined the mycorrhizal dependency of a plant based on the relationship between dry mass of the plants inoculated with a mycorrhizal fungus and the dry mass of uninoculated plants. Fungal isolates within one species vary in mycorrhizal effectiveness. When tested on a single host plant species, different mycorrhizal fungus isolates can increase, decrease, or have little effect on plant growth (Burgess et al., 1994; Dosskey et al., 1990; Miller et al., 1985; Molina, 1979). Van der Heijden and Kuyper (2001) in addition to plant biomass, included $\mathrm{N}$ - and P-contents of the plant to describe symbiotic effectiveness. While working with plant pathogens in small grain it would be possible to define the symbiotic effectiveness of AM fungi by the grain yield (both quantitatively and qualitatively) and the inhibition of the pathogen development (not only affecting the yield, but also the inoculum production of the pathogen). Van der Heijden and Kuyper (2001) found that "plant origin" and "plant origin $\times$ soil type" had a large interaction on the symbiotic effectiveness both for AM fungi and ectomycorrhizal fungi. In their study it can be noted that ectomycorrhiza fungal origin had only a minor effect on symbiotic effectiveness. However, since their study of the fungal origin was only performed with ectomycorrhizal fungi, van der Heijden and Kuyper (2001) proposed that this was due to the fact that spores of ectomycorrhizal fungi spread more efficiently than seeds. While considering the AM fungi this relationship is the opposite, the AM fungi with their spores solely produced in the soil or roots would spread much less efficiently than most plant seeds.

\section{AM fungi suppressiveness of $B$. sorokiniana}

The amount of AM fungal spores or their diversity does not tell to which extent the roots are colonised. More important, it does not tell what function the AM fungi have in the agroecosystem. One possible feature for the AM fungi is to reduce plant diseases. Following the extensive field survey the hypotheses was that the ability of AM fungi to suppress plant pathogens differed with the origin of the mycorrhizal fungi. By studying AM fungal populations from, for many years commonly cultivated, fields it is possible to identify AM fungi that can tolerate the impact of agriculture. Arbuscular mycorrhizal fungi collected from arable fields 
are therefore of value, both for the possibility to define agricultural practises stimulating symbiotic efficient AM fungi and for the option to use the AM fungi for disease suppression in practical farming.

In Paper II, AM fungi originating from fields of different agro climatic zones and crops, investigated in Paper I, were selected for a screening, considering their ability to interact with $B$. sorokiniana. Results of the survey showed that all, but two, AM fungal trap culture added as soil inocula resulted in a lower development of $B$. sorokiniana from the seed to the stem bases compared to the development of the pathogen in the plants with no added soil inocula from AM fungal trap cultures. One possible reason for this seems to be the elimination of AM fungi in sterilised soil.

Another interesting observation is the difference in inhibition between soil inocula from trap cultures of different origin. In the screening, AM fungi originating from a semi-natural grassland (Paper I; Table 2; trap culture no 29) indicated a beneficial effect on the germination of the B. sorokiniana-infected seeds and the survival of the barley plants. This trap culture originated from the indigenous soil with the highest number of different AM fungal spore types (Paper I). Among those AM fungal species there might have been some with opportunistic ability to colonise the first roots emerging from the seeds or at an early stage in other ways favouring the survival and growth of the barley plant. In semi-natural grasslands there is a dense layer of roots of several species of perennial grasses and herbs, which always might be colonised by AM fungi. However, every now and then there will be gaps in the plant cover, which will give new opportunities for seeds and AM fungi. Under such circumstances, a quick colonisation by AM fungi will be an ecological advantage. Based on this assumption, trap culture inocula originating from this semi-natural grassland were therefore selected for the second study.

The soil inoculum from the trap culture that gave rise to the highest percentage of healthy stem bases at harvest were the most disease suppressive and was also selected for the second experiment (Paper II; Table 2; trap culture no 41). This trap culture could possibly contain AM fungi to inhibit the development of $B$. sorokiniana to the stem bases. This trap culture inoculum originated from a farm that had been organically managed for several years, thus no chemical seed treatments were used inhibiting possible $B$. sorokiniana antagonistic AM fungi. The original soil was cultivated with barley with undersown ley at the sampling time, which might mean presence of multiplied AM fungi with a preference for barley. In addition, the undersown ley increase the plant diversity and thereby may promote a higher AM fungal diversity. However, the proportion healthy stem bases were also relatively high for the barley plants growing in pots inoculated with trap cultures originating from a barley field in the northern part of the country (Paper II; Table 2; soil number 6) as well as those originating from a field with ley in the southern part of the country (Paper II; Table 2; trap culture no 43).

In the successive study soil inocula from a trap culture originating from the semi-natural grassland with trap culture no 29 (Paper II; Table 1) and the barley field with trap culture no 41 (Paper II; Table 1) gave similar results as in the preceeding screening; trap culture inoculum originating from the semi-natural 
grassland resulted in more living plants and taller plants at harvest, while trap culture inoculum originating from the organically managed barley field resulted in a tendency for lower amounts of B. sorokiniana being detected on the stem bases (Paper II; Table 4). The trap culture inocula of native origins from Sweden were more efficient in inhibiting the development of B. sorokiniana, compared to the AM fungal commercial inoculum (Vaminoc ${ }^{\circledR}$ ) included in the study (Table 5). This indicate that although the AM fungi might have general benefits for the crop production AM fungi from different origins differ in their abilities to suppress specific pathogens.

It should however be remembered that also the commercial inoculum inhibited the development of B. sorokiniana upwards the barley stems (Paper II; Table 5). A speculation is also that the AM fungi from the semi-natural grassland might not be adapted to circumstances in more intensively cultivated fields, including ploughing. Therefore, the AM fungi originating from semi-natural grassland were not included in the proceeding experiment. For a third greenhouse experiment, using spore inocula, the AM fungi originating from the organically managed barley field (Paper II; Table 1; reference number 41) were used, in addition to AM fungi from other ploughed fields.

In the soil inocula from the trap cultures, there are probably other micro organisms than AM fungi multiplied as well, which could have an influence on the pathogen and/or the plant (Alström, 1987; Åström, 1990; Knudsen et al., 1997). By using AM fungal spore mixture as inocula in a third experiment such microorganisms were avoided. Possible differences between the substrates were also avoided, which could have an influence of the result (e.g. substate of Vaminoc ${ }^{\circledR}$ and trap cultures respectively). The inocula thus contained the AM fungi that had sporulated at the time for inocula collection and had also managed to survive the storage time of six months. For the option to inoculate AM fungi into arable fields in the practical farming the ability of the AM fungi to remain viable during storage is of great value, although there is a potential for optimising the storage method. The spores were surface washed to reduce bacteria. The spore inocula thus obtained consisted of AM fungi and possible mycorrhiza associated bacteria (Garbaye, 1994). This is the same situation as in the arable fields, where the AM fungi is living in an environment surrounded by other microorganisms, thus the spores are never sterile on the surface in vivo. In present experiment with AM fungi spore inocula, the barley plants treated with AM fungi from either of the origin resulted in lower detection of $B$. sorokiniana on leaf bases, leaves and stem bases. Also the commercial inoculum with surface sterilised Glomus intraradices spores had a lower incidence of $B$. sorokiniana than the control, which show that AM fungi with no initial bacteria on the surface have an suppressive effect against B. sorokiniana. Multivariate statistics in terms of Principal Component Analysis did not show any groupings of the suppressiveness of $B$. sorokiniana in relation to physical analysis, crop or agroclimatic zones of the sites from where the trap cultures originated (Paper I). In the screening survey in Paper II there was a slight tendency for increased suppression of the pathogen with decreasing amount of easily available phosphorus in the indigenous soil from where the trap culture originated, but this was not statistically confirmed. However, the relationship 
between the function of the AM fungal isolates and parameters describing the collection site is important for the understanding of the AM systems.

Presented results may indicate that the AM fungi decrease the root-necroses caused by B. sorokiniana (Paper II), since the roots of the plants lacking AM fungi had the highest proportion of necroses. This is in accordance with the result of Dehn and Dehne (1986) who found a lower Cochliobolus sativus (B. sorokiniana) infection of root tissue if the roots were already colonised by AM fungi, in this case Glomus etunicatum. They proposed that the mechanism mediating the mycorrhiza-Common root rot interactions was correlated to a general change of host plant physiology induced by the establishment of the AM symbiosis. All three isolates of one AM fungal species tested were able to reduce disease intensity on the roots (Dehn and Dehne, 1986). Furthermore, disease intensity could be reduced by AM fungi in all ten varieties of wheat and barley tested, but the degree of resistance varied with the genotype of host and pathogen (three C. sativus isolates were included). However, the degree of AM fungi colonisation of barley root was not correlated to their inhibition of common root rot (Dehn and Dehne, 1986).

In the present study the development of $B$. sorokiniana in stem bases, leaf bases, and leaves were inhibited although the AM fungi root colonisation was low (Paper II). This shows that AM fungi are able to suppress the B. sorokiniana development in barley plants, not only in the roots as shown by Dehn and Dehne (1986), but also in the above ground parts of the plants were the AM fungi is not present. Importantly, the pathogen was suppressed although the non-AM fungal plants was taller, which show that non-P-mediated mechanisms may be involved. This may indicate SAR and in that case seem to be initiated also with a low degree of AM fungal colonisation, although the mechanism mediating the mycorrhiza-disease interactions needs further investigation. The plant inoculated with AM fungal spores originating from the barley seed with undersown ley (Paper II; Table 1; trap culture no 41) had a three times lower risk of having a leaf base or leaf infected with B. sorokiniana (Paper II, Table 6) compared to the control, lacking AM fungi. Almost all other plants inoculated with AM fungal spores from other origins had an even lower risk of having a leaf base or leaf spot infected with $B$. sorokiniana. The AM fungal spores giving rise to the healthiest plants, with less than ten times lower risk of having a leaf base or leaf infected with B. sorokiniana (Paper II, Table 6) originated from fields with winter-wheat and barley respectively (Paper II, Table 1, trap culture no 23 and 33). In an Australian study AM fungal colonisation of crop and pasture species was negatively correlated with root infection by B. sorokiniana (Thompson and Wildermuth, 1989). They proposed that this indicates that AM fungi antagonise root infection by $B$. sorokiniana. It seems like the pathogen is locally inhibited by the AM fungus in tissues already colonised by the AM fungus, but the pathogen are able to infect AM fungi free tissues. However, the presence of AM fungi also seem to induce a change of host plant physiology independent of the degree of colonisation (Dehn and Dehne, 1986; Paper II, Paper III). This might explain why Thompson and Wildermuth (1989) did not find a correlation between degree of AM fungal colonisation and infection of stem bases with B. sorokiniana. 
An attempt to explain observed responses by AM fungi towards $B$. sorokiniana in the plant is by means of SAR, but can also be due to an altered nutrient status of the plant. However, an improved nutrient status due to AM fungal colonisation is often shown to be correlated to an increase in foliar diseases (Whipps, 2004). To be able to study the development of the necroses on the leaf of the actual host species, with only the AM fungi and the pathogen present an in vitro method was developed. For in vitro studies, of the AM fungal effect in the plant to inoculation of a pathogen, so far transgenic carrot roots have been used, which are normally resistant to the pathogen examined (Benhamou et al., 1994). The developed method makes it possible to analyse possible biochemical differences between mycorrhizal and nonmycorrhizal host plants, challenged by a pathogen. The leaf spots caused by $B$. sorokiniana were shorter on the plants inoculated with AM fungi, compared to the control plants, lacking AM fungi at all times (Paper III, Figure 2). The M-medium was chosen since this is a common growth medium for AM fungal cultures. By using a medium with less amount of carbon it would be possible to further develop this technique for studying the effect of $B$. sorokiniana or other pathogens inoculated in the roots. With M-medium the B. sorokiniana seem to prefer the medium and not the root. It would also be possible to use different levels of, for example, phosphorus in the media. A further development of in vitro techniques for studying the effect of AM fungi on disease development in different host plants or the mechanisms involved would be to grow AM fungal colonised plants in meristem cultures (Morel and Martin, 1952; Conger, 1981) or in embryo cultures (Hännig, 1904; Lange, 1969; Yeung et al., 1981). Meristem and embryo cultures are used for in vitro cultivation of plant pathogen free material. Although these techniques are probably more time consuming, than surface sterilising of seeds, and the survival of the plant material might be reduced in the initial stage, this would probably give rise to less contaminations of unwanted organisms in the actual experiments.

\section{Competition}

Evolutionary, plants have evolved with both the AM fungi and the pathogens present. Consequently, since B. sorokiniana and AM fungi live in the same habitats, the soil and the root, these organisms also evolved together and probably developed defence strategies towards each other. One strategy by the AM fungi seem to be the induction of SAR restricting the development of B. sorokiniana, although more research is needed to explore the biochemical changes and to exclude the possible influence of an altered nutrient status. Other strategies might develop in the soil, for example at the pre-infection/colonisation stage, when AM fungi presumably do not have the ability to gain more energy in contrast to $B$. sorokiniana with its ability to live saprophytically. Aiming to develop tools for biocontrol, it is desirable to identify the interactions between the pathogen and the potential biocontrol agent. The observation from this study that there was a low AM fungal colonisation in the roots of the barley plants naturally infected with seed-borne B. sorokiniana (Paper II) led to the suspicion that B. sorokiniana might as well inhibit the AM fungi. Therefore, a series of in vitro studies were conducted. In addition, the possible direct inhibition of $B$. sorokiniana conidia germination by exudate filtrates of AM fungal extraradical mycelium were 
examined (Paper III). Roots produce a huge array of organic chemicals of which are released to the surrounding soil (Rovira, 1969; Whitfield et al., 1981; Curl and Truelove, 1986). The compounds that are released by roots were classified by Rovira and Daveys (1974) according to their mobility in soil; 1) diffusible-water soluble, 2) diffusible-volatile and 3) non-diffusible compounds. The efficacy of volatile compounds as messengers in soil is well documented (Stotzky and Schenck, 1976). The germination and hyphal growth of AM fungal spores are also influenced by different compounds released by soil micro-organisms (Mc Allister et al., 1996; Paper III). Paper III showed that AM fungal spore germination are reduced by the presence both of $B$. sorokiniana growing on the same medium, or by its exudate filtrates or volatile compounds released by the plant pathogen while growing in nutrient rich medium. However, the possible volatile compounds did not affect AM spore germination when the plant pathogen was growing in nutrient deficient medium.

In practical farming this might mean that less nutrient near the germinating seed promote the AM fungal spore germination in the presence of soil-borne $B$. sorokiniana. The presence of exudate filtrates of $B$. sorokiniana inhibited the Glomus intraradices spore germination day 4-8. Later there were no inhibition, which might be due to the fact that the exudate had diffused down in the media. Different AM fungal species, or even different isolates of AM fungal species might however react differently towards $B$. sorokiniana and the reaction in laboratory might not be the same as in the field. However Paper III shows that exudate filtrates of B. sorokiniana inhibit not only $G$. intraradices, but also $G$. proliferum and this inhibition proceded at least until day 19. For statistical reasons, the hyphal growth of the germinated spores were divided in two categories, those that only grow a short distance and those that went on growing and branching. The statistical analyses thus did not show any difference in hyphal growth for the B. sorokiniana treated AM fungal spores and the control (which was not treated with B. sorokiniana) in any of the experiments. However, there might still have been differences in hyphal growth in a smaller scale (length of hyphae at different time intervals). For further comparisons of the hyphal growth a higher number of germinated AM fungal spores have to be analysed.

The conidia germination of $B$. sorokiniana does not seem to be affected by exudate filtrates of AM fungi to any great extent (Paper III; Table 4). However, the direct interaction between B. sorokiniana and a developed AM fungal hyphal network connected to living roots need to be examined as well as the ability of AM fungi, with ability to suppress $B$. sorokiniana, to suppress other pathogens. Development of methods for favouring the germination and establishment of AM fungi on the barley seedlings in the field to prevent infection by air-, seed- or soilborne infections and/or transmission of pathogens is crucial. The pathogens provide all the signals that the plant has evolved to react to in terms of defences. However, the pathogen cause some level of economic loss to the crop. Arbuscular mycorrhizal fungi also evolved with the plant. Studies show that AM fungi induce defence mechanisms in the plant towards certain pathogens under some growing conditions (Cordier, et al., 1998; Paper II; Paper III). In contrast to the pathogen the AM fungi often not even cause trivial or unmeasurable levels of damage to the 
crop, but actually also give several other benefits to the plant, like increase the phosphorus uptake and the resistance towards $B$. sorokiniana.

By identifying circumstances when the AM fungi best protect the crop against pathogens, tools will be available to exploit the AM fungi. There are several possibilities by using the AM fungi to reduce the loss in quality and quantity of the yield due to the pathogens caused by $B$. sorokininan. One option might be to introduce an alien AM fungi, which have been selected in screenings to have a high level of suppression ability of the pathogen, to the field. Due to the obligate biotrophic nature of the AM fungi they are relatively costly to multiply. In addition, it might be difficult to predict the activity of the specific AM fungi introduced, since soil biological parameters vary substantially. A better option might be to elaborate the cultivation practises to promote the mutualistic value of the AM fungal communities already existing. In addition, this could be combined with the addition of saprophytic bacteria or fungi acting by other modes of action against the pathogen than the AM fungi. This might give synergistic effects.

\section{Conclusions}

With this work I have been able to conclude that;

- arbuscular mycorrhizal fungi are present in a wide range of arable fields in Sweden, at the 45 sampling sites the AM fungal spore densities varied from 3 up to 44 spores per gram air dried soil,

- arbuscular mycorrhiza fungal trap cultures, pure G. intraradices and unsterilised spore-mixtures of arbuscular mycorrhizal fungi are able to suppress the development of seed-borne B. sorokiniana in barley. The degree of suppression of the development of $B$. sorokiniana varies with the origin of arbuscular mycorrhiza fungal trap cultures and unsterilised spore-mixtures of arbuscular mycorrhizal fungi,

- in vitro studies showed that Bipolaris sorokiniana decrease spore germination of AM fungal species,

- in vitro studies indicate that presence of AM fungi decrease the lesion development of the leaf due to inoculation of $B$. sorokiniana,

- by using the developed in vitro host plant method it will be possible to study the impact of AM fungi on the development of plant foliar diseases.

Thus, it is a clear potential for using AM fungi in crop production, not only to promote crop growth in general, but also specifically to suppress diseases caused by $B$. sorokiniana. 


\title{
Abbreviations
}

\author{
AM fungi Arbuscular mycorrhizal fungi \\ $H R \quad$ Hypersensitive response \\ SAR Systemic Aquired Resistance
}

\section{Glossary of useful terms}

\begin{tabular}{|c|c|}
\hline Antagonism & the inhibitory action of one species on another \\
\hline Arbuscule & $\begin{array}{l}\text { complex branched treelike, hyphal systems within the cell of } \\
\text { the plant root }\end{array}$ \\
\hline Biotroph & $\begin{array}{l}\text { an organism that can live and multiply on another living } \\
\text { organism }\end{array}$ \\
\hline Chlorosis & $\begin{array}{l}\text { yellowing of normally green tissue due to chlorophyll } \\
\text { destruction or failure of chlorophyll formation }\end{array}$ \\
\hline Conidia & non-motile, asexual spores \\
\hline Cotyledon & $\begin{array}{l}\text { the first leaf or leaves of a seed plant, found in the embryo, and } \\
\text { which may form the first photosynthetic leaves or may remain } \\
\text { below ground }\end{array}$ \\
\hline Distoseptates & $\begin{array}{l}\text { individual cells each surrounded by a sac-like wall distinct } \\
\text { from the outer wall }\end{array}$ \\
\hline Fungal pegs & $\begin{array}{l}\text { penetration of plant epidermal cells by individual hyphal } \\
\text { "pegs" in monotropoid mycorrhiza }\end{array}$ \\
\hline Fungicide & a compound toxic to fungi \\
\hline Gnotobiotics & $\begin{array}{l}\text { the study of organisms or species when other organisms or } \\
\text { species are absent }\end{array}$ \\
\hline Herbicide & a compound toxic to plants \\
\hline Hypha & $\begin{array}{l}\text { tubular filament that is the structural growth unit of filamentous } \\
\text { fungi }\end{array}$ \\
\hline Hypocotyls & $\begin{array}{l}\text { that portion of stem below cotyledons in plant embryo, which } \\
\text { eventually bears the roots }\end{array}$ \\
\hline Mycelium & $\begin{array}{l}\text { network of hyphae, the characteristic vegetative phase of many } \\
\text { fungi }\end{array}$ \\
\hline Mycorrhiza & the symbiotic association between a fungi and a plant \\
\hline Mycorrhizospl & the soil influenced by the mycorrhizal roots and mycelia \\
\hline Necrosis & death of cells or tissues \\
\hline Obligate & limited to one mode of life or action \\
\hline Opportunistic & species specialised to exploit newly opened habitat \\
\hline $\begin{array}{l}\text { Peleton } \\
\text { mycorrhiza }\end{array}$ & hyphal coils formed in cortical cells in orchidaceous \\
\hline Phylum & a taxonomic rank between kingdom and class; a division \\
\hline Rhizosphere & the soil influenced by roots \\
\hline Saprotroph & organism that feeds on dead organic matter \\
\hline
\end{tabular}


Siderophore

Specificity

Vesicles a metabolic product of a fungus (or other organism) which binds iron and facilitates its transport from the environment into the microbial cell (from the Greek meaning "iron carrier") being limited to a species

lipid rich storage organ 


\section{References}

Abbott, L.K. \& Robson, A.D. 1991. Factors influencing the occurrence of vesiculararbuscular mycorrhizas. Agriculture, Ecosystem and Environment 35, 121-150.

Abdel-Fattah, G.M. \& Shabana, Y.M. .2002. Efficacy of the arbuscular mycorrhizal fungus Glomus clarum in protection of cowpea plants against root rot pathogen Rhizoctonia solani. Journal of Plant Disease Protection 109, 207-215.

Aguilera, L.E., Guiterrez, J.R. \& Moreno, R.L. 1998. Vesiculo arbuscular mycorrhizae associated with saltbushes Atriplex spp. (Chenopodiaceae) in the Chilean arid zone. Revista-Chilena-de Historia-Natural (Chile) 71, 291-302.

Al-Garni, S.M. \& Daft, M.J. 1990. Occurrence and effectiveness of vesicular-arbuscular mycorrhizas in agricultural soils from Saudi Arabia. Biological Agriculture and Horticulture 7, 69-80.

Al-Hashimi, M.H. \& Perry, D.A. 1986. Survival and saprobic ability of Monographella nivalis in soil. Transactions of the British Mycological Society 86, 373-379.

Alcorn, J.L. 1988. The taxonomy of "Helminthosporium" species. Annual Review of Phytopathology 26, 37-56.

Allen, E.B. \& Allen, M.F. 1980. Natural re-establishment of vesicular-arbuscular mycorrhizae following stripmine reclamation in Wyoming. Journal of Applied Ecology 17, 139-147.

Allen, M.F., Moore, T.S. \& Christensen, M. 1980. Phytohormone changes in Bouteloua gracilis infected by vesicular-arbuscular mycorrhizae I; Cytokinin increases in the host plant. Canadian Journal of Botany 58, 371-374.

Allen, M.F., Moore, T.S. \& Christensen, M. 1982. Phytohormone changes in Bouteloua gracilis infected by vesicular-arbuscular mycorrhizae II; Altered levels of gibberellin-like substances and abscisic acid in the host plant. Canadian Journal of Botany 60, 468-471.

Alström, S. 1987. Influence of root-zone inhabiting bacteria on growth of plants and soilborne fungal pathogens. Doctoral thesis, Plant protection reports 14, SLU.

Andrade, G., Linderman, R.G. \& Bethlenfalvay, G.J. 1998. Bacterial associations with the mycorrhizosphere and hyphosphere of the arbuscular mycorrhizal fungus Glomus mosseae. Plant and Soil 202, 79-87.

Andrade, G., Mihara, K.L., Linderman, R.G. \& Bethlenfalvay, G.J. 1997. Bacteria from rhizosphere and hyphosphere soils of different arbuscular-mycorrhizal fungi. Plant and Soil 192, 71-79.

Åström, B. 1990. Interactions between plants and deleterious rhizosphere bacteria importance of plant genotype and possible mechanisms involved. Doctoral thesis, Plant protection reports 19 , SLU.

Azcón, R. 1987. Germination and hyphal growth of Glomus mosseae in vitro: effect of rhizosphere bacteria and cell-free culture media. Soil Biology and Biochemistry 19, 417419.

Azcon, R. \& Ocampo, J.A. 1981. Factors affecting the vesicular-arbuscular infection and mycorrhizal dependency of thirteen wheat cultivar. New Phytologist 87, 677-689.

Azcón-Aguilar, C., Diaz-Rodriguez, R.M. \& Barea, J.M. 1986. Effect of soil microorganisms on spore germination and growth of the vesicular arbuscular mycorrhizal fungus Glomus mosseae. Transactions of the British Mycological Society 86, 337-340.

Azcon-Aguilar, C. \& Barea, J.M. 1985. Effects of soil microorganisms on formation of vesicular-arbuscular mycorrhizas. Transactions of the British Mycological Society 84, 536-537.

Bago, B., Pfeffer, P.E., Abubaker, J., Jun, J., Allen, J.W., Brouillette, J., Douds, D.D., Lammers, P.J. \& Shachar-Hill, Y. 2003. Carbon export from arbuscular mycorrhizal roots involves the translocation of carbohydrate as well as lipid. Plant Physiolology 131, 1496-1507.

Bago, B., Zipfel, W., Williams, R.M., Jun, J., Arreola, R., Lammers, P.J., Pfeffer, P.E. \& Shachar-Hill, Y. 2002. Translocation and utilization of fungal storage lipid in the arbuscular mycorrhizal symbiosis. Plant Physiology 128, 108-124. 
Bailey, K.L., Mortensen, K. and Lafond, G.P. 1992. Effects of tillage systems and crop rotation on root and foliar diseases of wheat, flax, and peas in Saskatchewan. Canadian Journal of Plant Science 72, 583-591.

Bakker, P.A.H.M., van Peer, R. \& Schippers, B. 1990. Specificity of siderophores and siderophore receptors and biocontrol by Pseudomonas spp. In: Biological control of soilborne plant pathogens. (Eds. D. Hornby). CAB International, Wallingford, pp. 131142.

Bakonyi, J., Aponyi, I. \& Fischl, G. 1998. Diseases caused by Bipolaris sorokiniana and Drechslera tritici-repentis in Hungary. In: Helminthosporium blight of wheat: Spot Blotch and Tan Spot, pp. 18-27. (Eds. E Duveiller, HJ Dubin, J Reeves and A McNab). Proceedings of an international workshop held at CIMMYT, 9-14 February 1997. El Batan, Mexico. ISBN 970-648-001-3.

Bearden, B. \& Petersen, L. 2000. Influence of arbuscular mycorrhizal fungi on soil structure and aggregate stability of a vertisol. Plant and Soil 218, 173-183.

Bécard, G. \& Fortin, J.A. 1988. Early events of vesicular-arbuscular mycorrhiza formation in Ri T-DNA transformed roots. New Phytologist 108, 211-218.

Beilby, J.P. 1983. Effects of inhibitors on early protein, RNA, and lipid synthesis in germinating vesicular-arbuscular mycorrhizal fungal spores of Glomus caledonium. Canadian Journal of Botany 29, 596-601.

Beilby, J.P. \& Kidby, D.K. 1980. Biochemistry of ungerminated and germinated spores of the vesicular-arbuscular mycorrhizal fungus Glomus caledonium: changes in neutral and polar lipids. Journal of Lipid Research 21, 739-750.

Benhamou, N., Fortin, J.A., Hamel, C., St-Arnaud, M. \& Shatilla, A. 1994. Resistance responses of mycorrhizal Ri T-DNA-transformed carrot roots to infection by Fusarium oxysporum f. sp. Chrysanthemi. Phytopathology 84, 958-968.

Bevege, D.I. \& Bowen, G.D. 1975. Endogone strain and host plant differences in development of vesicular-arbuscular mycorrhizas. In: Endomycorrhizas. (Eds. FE Sanders, B Mosse and PB Tinker). Academic Press, London, UK, pp. 77-86.

Bioagri, Sweden. www.bioagri.se (English version read August 2005)

Black, R. \& Tinker, P.B. 1979. The development of endomycorrhizal root systems II; Effect of agronomic factors and soil conditions on the development of vesiculararbuscular mycorrhizal infection in barley and on the endophyte spore density. New Phytologist 83, 401-413.

Blaszkowski, J. 1993. Comparative studies on the occurrence of arbuscular fungi and mycorrhizae (Glomales) in cultivated and uncultivated soils of Poland. Acta Mycologia $28,93-140$.

Blee, K.A. \& Anderson, A.J. 1996. Defense-related transcript accumulation in Phaseolus vulgaris L. colonized by the arbuscular mycorrhizal fungus Glomus intraradices Schenck \& Smith. Plant Physiology 110, 675-688.

Boddington, C.L. \& Dodd, J.C. 2000a. The effect of agricultural practices on the development of indigenous arbuscular mycorrhizal fungi I; Field studies in an Indonesian ultisol. Plant and Soil 218, 137-144.

Boddington, C.L. \& Dodd, J.C. 2000b. The effect of agricultural practices on the development of indigenous arbuscular mycorrhizal fungi II; Studies in experimental microcosms. Plant and Soil 218, 145-157.

Borowicz, V.A. 2001. Do arbuscular mycorrhizal fungi alter plant-pathogen relations? Ecology 82, 3057-3068.

Boyetchko, S.M. \& Tewari, J.P. 1995. Susceptibility of barley cultivars to vesiculararbuscular mycorrhizal fungi. Canadian Journal of Plant Science 75, 269-275.

Brundrett, M.C., Piché, Y. \& Peterson, R.L. 1985. A developmental study of early stages in vesicular-arbuscular mycorrhiza development. Canadian Journal of Botany 63, 184-194.

Burgess, T., Dell, B. \& Malajczuk, N. 1994. Variation in mycorrhizal development and growth stimulation by 20 Pisolithus isolates inoculated on Eucalyptus grandis W. Hill ex Maiden. New Phytologist 127, 731-739.

Burrows, R.L. \& Pfleger, F.L. 2002. Arbuscular mycorrhizal fungi respond to increasing plant diversity. Canadian Journal of Botany 80, 120-130. 
Cabello, M.L., Gaspar, L. \& Pollero, R. 1994. Glomus antarcticum sp. Nov., a vesiculararbuscular mycorrhizal fungus from Antarctica. Mycotaxon 51, 123-128.

Caproni, A.L., Franco, A.A., Berbara, R.L.L., Trufem, S.B., Granha, J.R.D. \& Monteiro, A.B. (2003) Arbuscular mycorrhizal fungi occurrence in revegetated areas after bauxite mining at Porto Trombetas, Para state, Brazil. Pesquisa-Agropecuária-Brasileira 38, 1409-1418.

Carling, D.E. \& Brown, M.F. 1980. Relative effect of vesicular-arbuscular mycorrhizal fungi on the growth and yield of soybeans. Soil Science Society American Journal 44, 528-532.

Carling, J. \& Joner, U. 1998. Regional divisions in Swedish agricultural statistics 1998. Reports on statistical co-ordination for the official statistics of Sweden 1998:1, SCBTryck, Örebro, Sweden. ISSN 1402-0807. (In Swedish)

Carlson, H., Stenram, U., Gustafsson, M. \& Jansson, H.B. 1991. Electron microscopy of barley root infection by the fungal pathogen Bipolaris sorokiniana. Canadian Journal of Botany 12, 2724-2731.

Caron, M., Fortin, J.A. \& Richard, C. 1986. Effect of inoculation sequence on the interaction between Glomus intraradices and Fusarium oxysporum f. sp. radicislycopersici in tomatoes. Canadian Journal of Plant Pathology 8, 12-16.

Century, K.S., Holub, E.B. \& Staskawicz, B.J. 1995. NDR1, a locus of Arabidopsis thaliana that is required for disease resistance to both a bacterial and a fungal pathogen. Proceedings of the National Academy of Sciences of the United States of America 92, 6597-6601.

Chester, K.S. 1933. The problem of aquired physiological immunity in plants. Quarterly Reviews of Biology 8, 275-324.

Citernesi, A.S., Fortuna, P., Filippi, C., Bagnoli, G. \& Giovannetti, M. 1996. The occurrence of antagonistic bacteria in Glomus mosseae pot cultures. Agronomie 16, 671677.

Cohen, Y. \& Kuc, J. 1981. Evaluation of systemic resistance to blue mold induced in tobacco leaves by prior stem inoculation with Peronospora hyoscyami f. sp. tabacina Biological control. Phytopathology 71, 783-787.

Conger, B.V. 1981. Cloning agricultural plants via in vitro techniques. CRC Press, Florida, USA. 273 pp.

Cordier, C., Pozo, M. J., Barea, J. M., Gianinazzi, S. \& Gianinazzi-Pearon, V. 1998. Cell defense response associated with localized and systemic resistence to Phytophthora parasitica induced in tomato by arbuscular mycorrhizal fungus. Molecular PlantMicrobe Interactions 11, 1017-1028.

Cox, G., Sanders, F.E., Tinker, P.B. \& Wild, J.A. 1975. Ultrastructural evidence relating to host-endophyte transfer in vesicular-arbuscular mycorrhizas. In: Endomycorrhizas (Eds. F.E. Sanders, B. Mosse \& P.B. Tinker). Academic Press, London, pp. 297-312.

Cress, W.A., Johnson, G.V. \& Barton, L.L. 1986. The role of endomycorrhizal fungi in iron uptake by Hilaria jamesii. Journal of Plant Nutrition 9, 547-556.

Crush, J.R. 1975. Occurrence of endomycorrhizas in soils of the Mackenzie Basin, Canterbury, New Zealand. New Zealand Journal of Agricultural Reserach 18, 361-364.

Curl, E.A. \& Truelove B. 1986. The rhizosphere. Advanced series in agricultural sciences 15. Springer-Verlag, Berlin, Germany. 288 pp.

Daamen, R.A., Wijnands F.G. \& van der Vliet G. 1988. Disease and pest development in different winter barley cropping systems. In: Cereal breeding related to integrated cereal production. (Eds. ML Journa and LAJ Slootmaker). Wageningen: PUDOC, pp 38-43.

Daamen, R.A., Wijnands F.H. \& van der Vliet G. 1989. Epidemics of diseases and pests of winter wheat at different levels of agrochemical input. Journal of Phytopathology 125, 305-319.

Dalpé, Y. \& Aiken S.G. 1998. Arbuscular mycorrhizal fungi associated with Festuca species in Canadian High Arctic. Canadian Journal of Botany 76, 1930-1938.

Daniell T.J., Husband R., Fitter A.H. \& Young J.P.W. 2001. Molecular diversity of arbuscular mycorrhizal fungi colonising arable crops. FEMS Microbiology Ecology 36, 203-209. 
Davies, F.T., Porter J.R. \& Linderman R.G. 1993. Drought resistance of mycorrhizal pepper plants independent of leaf $\mathrm{P}$ concentration-response in gas exchange and water relations. Physiologia Plantarum 87, 45-53.

Davies, F.T., Puryear J.D., Newton R.J., Egilla J.N. \& Saraiva Grossi J.A. 2001. Mycorrhizal fungi enhance accumulation and tolerance of chromium in sunflower (Helianthus annuus). Journal of Plant Physiology 158, 777-786.

Davis, R.M. \& Menge J.A. 1980. Influence of Glomus fasciculatus and soil phosphorus on Phytophthora root rot of citrus. Phytopathology 70, 447-452.

Davis, R.M., Menge J.A. \& Zentmeyer G.A. 1978. Influence of vesicular-arbuscular mycorrhizae on Phytophthora root rot of three crop plants. Phytopathology 68, 16141617.

Declerck, S., Risede, J.M., Rufyikiri, G. \& Delvaux, B. 2002. Effects of arbuscular mycorrhizal fungi on severity of root rot of bananas caused by Cylindrocladium spathiphylli. Plant Pathology 51, 109-115.

Dehn, B. and Dehne, H.W. 1986. Development of VA mycorrhizal fungi and interactions with Cochliobolus sativus in roots of gramineae. In: Physiological and genetical aspects of mycorrhizae. (Eds. V. Gianinazzi Pearson \& S. Gianinazzi). Institut National de la Recherche Agronomique, Paris, France, pp. 773-779.

Dehne, H.W. 1982. Interaction between vesicular arbuscular mycorrhizal fungi and plant pathogens. Phytopathology 72, 1115-1119.

Dehne, H.W. 1987. VA mycorrhiza and plant health. In: Mycorrhizae in the Next Decade: Practical Applications and Research Pririties. (Ed. D.M. Sylvia) Proceedings of the $7^{\text {th }}$ North American Conference on Mycorrhizae, Gainesville, USA, p. 192.

Dehne, H.W. \& Oerke, E.C. 1985. Investigations on the occurrence of Cochliobolus sativus on barley and wheat I; Influence of pathogen, host plant and environment on infection and damage. Journal of Plant Diseases and Protection 92, 270-280. (In German with English summary)

Dixon, R.A., Harrison, M.J. \& Lamb, C.J. 1994. Early events in the activation of plant defense responses. Annual Review of Phytopathology 32, 479-501.

Dodd, J.C., Arias, I., Koomen, I. \& Hayman. 1990. The management of populations of vesicular-arbuscular mycorrhizal fungi in acid-infertile soils of a savanna ecosystem II; The effects of pre-cropping on the spore populations of native and introduced VAMfungi. Plant and Soil 122, 241-247.

Dosskey, M.G., Linderman, R.G. \& Boersma, L. 1990, Carbon-sink stimulation of photosynthesis in Douglas fir seedlings by some ectomycorrhizae. New Phytologist 115, 269-274.

Droby, S., Chalutz, E., Wilson, C.L. \& Wisniewski, M. 1989. Characterization of the biocontrol activity of Debaryomyces hansenii in the control of Penicillium digitatum on grapefruit. Canadian Journal of Microbiology 35, 794-800.

Duczek, L. 1984. Comparison of the common root rot reaction of barley lines and cultivars in northwestern Alberta and central Saskatchewan. Canadian Journal of Plant Pathology 6, 81-89.

Duczek, L.J. 1997. Biological control of common root rot in barley by Idriella bolleyi. Canadian Journal of Plant Pathology 19, 402-405.

Duczek, L.J., Jones-Flory, L.L., Reed, S.L., Bailey, K.L. \& Lafond, G.P. 1996. Sporulation of Bipolaris sorokiniana on the crowns of crop plants grown in Saskatchewan. Canadian Journal of Plant Science 76, 861-867.

Edington, B.V., Lamb, C.J. \& Dixon, R.A. 1991. cDNA cloning and characterization of a putative 1,3-beta-glucanase transcript induced by fungal elicitor in bean cell suspension cultures. Plant Molecular Biology 16, 81-94.

Elias, K.S. \& Safir, G.R. 1987. Hyphal elongation of Glomus fasciculatus in response to root exudates. Applied and Environmental Microbiology 53, 1928-1933.

Enyedi, A.J., Yalpani, N., Silverman, P. \& Raskin, I. 1992. Signal molecules in systemic plant resistance to pathogens and pests. The Cell 70, 879-886.

Eriksson, A. 2001. Arbuscular mycorrhiza in relation to management history, soil nutrients and plant species diversity. Plant Ecology 155, 129-137. 
Filion, M., St-Arnaud, M. \& Fortin, J.A. 1999. Direct interaction between the arbuscular mycorrhizal fungus Glomus intraradices and different rhizosphere microorganisms. New Phytologist 141, 525-533.

Filion, M., St-Arnaud, M. \& Jabaji-Hare, S.H. 2003. Quantification of Fusarium solani f. sp. phaseoli in mycorrhizal bean plants and surrounding mycorrhizosphere soil using real-time polymerase chain reaction and direct isolations on selective media. Phytopathology 93, 229-235.

Fokkema, N.J. 1971. The effect of pollen in the phyllosphere of rye on colonization by saprophytic fungi and on infection by Helminthosporium sativum and other leaf pathogens. Netherlands Journal of Plant Pathogens 77 (Suppl. 1), 1.

Fokkema, N.J. 1973. The role of saprophytic fungi in antagonism against Drechslera sorokiniana (Helminthosporium sativum) on agar plates and on rye leaves with pollen, Physiological Plant Pathology 3, 195-205.

Forsberg, G. 2004. Control of cereal seed borne diseases by hot humid air seed treatment. Doctoral thesis, SLU. Acta Universitatis Agriculturae Suecia. Agraria 443.

Francis, R. \& Read, D.J. 1984. Direct transfer of carbon between plants connected by vesicular arbuscular mycorrhizal mycelium. Nature 307, 53-56.

Frank, A.B. 1885. Über die auf Wurzelsymbiose beruhende Ernährung gewisser Baume durch unterirdische Pilze. Berichte der Deutsche Botanische Gesellschaft 3, 128-145. (In German)

Friese, C.F. \& Allen, M.F. 1991. The spread of VA mycorrhizal hyphae in the soil: inoculum types and external hyphal architecture. Mycologia 83, 409-418.

Fusconi, A., Gnavi, E., Trotta, A. \& Berta, G. 1999. Apical meristems of tomato roots and their modifications induced by arbuscular mycorrhizal and soilborne pathogenic fungi. New Phytology 142, 505-516.

Gallaud, I. 1905. Etudes sur les mycorrhizes endotrophs. Revue Générale de Botanique 17, pp. 5-50. (In French)

Ganesan, V., Ragupathy, S., Parthipan, B., Rajini-Rani, D.B. \& Mahadevan, A. 1991. Distribution of vesicular-arbuscular mycorrhizal fungi in coal, lignite and calcite mine spoils of India. Biology and Fertility of Soils 12, 131-136.

Gange, A.C., Brown, V.K. \& Farmer, L.M. 1990. A test of mycorrhizal benefit in an early successional plant community. New Phytologist 115, 85-91.

Gange, A.C., Brown, V.K. \& Sinclair, G.S. 1993. Vesicular-arbuscular mycorrhizal fungi: a determinant of plant community structure in early succession. Functional Ecology 7, 616-622.

Garbaye, J. 1994. Transley Review No 76. Helper bacteria: a dimension to the mycorrhizal symbiosis. New Phytologist 128, 197-210.

Garriock, M.L., Peterson, R.L. \& Ackerley, C.A. 1989. Early stages in colonization of Allium porrum (leek) roots by the vesicular-arbuscular mycorrhizal fungus, Glomus versiforme. New Phytologist 112, 85-92.

Gaspar, M.L., Pollero, R.J. \& Cabello, M.N. 1994. Triacylglycerol consumption during spore germination of vesicular-arbuscular mycorrhizal fungi. Journal of American Oil Chemistry Society 71, 449-452.

George, E., Marschner, H. \& Jakobsen, I. 1995. Role of arbuscular mycorrhizal fungi in uptake of phosphorus and nitrogen from soil. Critical Reviews and Biotechnology 15, 257-270.

Gerdemann, J.W. 1968. Vesicular-arbuscular mycorrhizae and plant growth. Annual Review of Phytopathology 6, 397-418.

Gerdemann, J.W. 1975. Vesicular-arbuscular mycorrhizae. In: The development and function of roots. (Eds. JG Torrey and DT Clarkson). Academic Press, New York, USA, pp 575-591.

Gerdemann, J.W \& Nicolson, T.H. 1963. Spores of mycorrhizal Endogone species extracted from soil by wet sieving and decanting. Transaction of the British Mycological Society 46, 235-244

Gianinazzi-Pearson, V. 1996. Plant cell responses to arbuscular mycorrhizal fungi: Getting to the roots of the symbiosis. The Plant Cell 8, 1871-1883. 
Gianinazzi-Pearson, V., Branzanti, B. \& Gianinazzi, S. 1989. In vitro enhancement of spore germination and early hyphal growth of a vesicular-arbuscular mycorrhizal fungus by host root exudates and plant flavanoids. Symbiosis 7, 243-255.

Giovannetti, M., Sbrana, C., Avio, L., Citernesi, A.S. \& Logi, C. 1993a. Differential hyphal morphogenesis in arbuscular mycorrhizal fungi during pre-infection stages. New Phytologist 125, 587-593.

Giovannetti, M., Avio, L., Sbrana, C. \& Citernesi, A.S. 1993b. Factors affecting appressorium development in the vesicular-arbuscular mycorrhizal fungus Glomus mosseae (Nicol. \& Gerd.) Gerd. and Trappe. New Phytologist 123, 115-122.

Godiard, L., Grant, M.R., Dietrich, R.A., Kiedrowski, S. \& Dangl, J.L. 1994. Perception and response in plant disease resistance. Current Opinion in Genetics and Development $4,662-671$.

Grace, C. \& Stribley, D.P. 1991. A safer procedure for routine staining of vesiculararbuscular mycorrhizal fungi. Mycological Research 19, 1160-1162.

Graham, J.H., Linderman, R.G. \& Menge, J.A. 1982. Development of external hyphae by different isolates of mycorrhizal Glomus spp. in relation to root colonisation and growth of Troyer citrange. New Phytologist 91, 183-189.

Graves, J.D., Watkins, N.K., Fitter, A.H., Robinson, D. \& Scrimgeour, C. (1997) Intraspecific transfer of carbon between plants linked by a common mycorrhizal network. Plant and Soil 192, 153-159.

Grime, J.P., Mackey, J.M.L., Hiller, S.H. \& Read, D.J. 1987. Floristic diversity in a model system using experimental microcosms. Nature 328, 420-422.

Gryndler, M. \& Vosatka, M. 1996. The response of Glomus fistulosum-maize mycorrhiza to treatments with culture fractions from Pseudomonas putida. Mycorrhiza 6, 207-211.

Hall, I.R. 1977. Species and mycorrhizal infections of New Zealand Endogonaceae. Transaction of the British Mycological Society 68, 341-356.

Hammond-Kosack, K.E., Silverman, P., Raskin, I. \& Jones, J.D.G. 1996. Race-specific elicitors of Cladosporium fulvum induce changes in cell morphology and the synthesis of ethylene and salicylic acid in tomato plants carrying the responding $C f$ disease resistance genes. Plant Physiology 110, 1381-1394.

Harborne, J.B. 1983. Toxins of plant-fungal interactions. In: Handbook of natural toxins; plant and fungal toxins. (Eds. R.F. Keeler \& A.T. Tu). Marcel Dekker, New York, USA, pp. 743-782.

Harinikumar, K.M. \& Bagyaraj, D.J. 1989. Effect of cropping sequence, fertilizers and farmyard manure on vesicular-arbuscular mycorrhizal fungi in different crops over three consecutive seasons. Biology and Fertility of Soils 7, 173-175.

Harley, J.L. 1959. The biology of mycorrhiza. Leonard Hill, London, UK.

Harley, J.L. \& Smith, S.E. 1983. Mycorrhizal symbiosis. Academic Press, London, UK.

Harrisson, M.J. \& Dixon, R.A. 1993. Isoflavanoid accumulation and expression of defense gene transcripts during the establishment of vesicular-arbuscular mycorrhizal associations in roots of Medicago truncatula. Molecular Plant-Microbe Interactions 6, 643-654.

Harrison, M.J. \& Dixon, R.A. 1994. Spatial patterns of expression of flavanoid/isoflavanoid pathway genes during interactions between roots of Medicago truncatula and the mycorrhizal fungus Glomus versiforme. The Plant Journal 6, 9-20.

Hartnett, D.C. \& Wilson, W.T. 1999. Mycorrhizae influence plant community structure and diversity in tall grass prairie. Ecology 80, 1187-1195.

Hawkins, H.J., Johansen, A. \& George, E. 2000. Uptake and transport of organic and inorganic nitrogen by arbuscular mycorrhizal fungi. Plant and Soil 226, 275-285.

Hayman, D.S., Barea, J.M. \& Azcon, R. 1976. Vesicular-arbuscular mycorrhiza in Southern Spain: its distribution in crops growing in soil of different fertility. Phytopathology Mediterranean 15, 1-6.

Heap, A.J. \& Newman, E.I. 1980. Links between roots by hyphae of vesicular-arbuscular mycorrhizas. New Phytologist 85, 169-171.

Hedlund, K. 2002. Soil microbial community structure in relation to vegetation management on former agricultural land. Soil Biology and Biochemistry 34, 1299-1307. 
Hedrick, S.A., Bell, J.N., Boller, T. \& Lamb, C.J. 1988. Chitinase cDNA cloning and mRNA induction by fungal elicitor, wounding, and infection. Plant Physiology 86, 182186.

Hirrel, M.C. \& Gerdemann, J.W. 1979. Enhanced carbon transfer between onions infected with a vesicular-arbuscular mycorrhizal fungus. New Phytologist 83, 731-738.

Hodge, A. 2000. Microbial ecology of the arbuscular mycorrhiza. FEMS Microbiology Ecology 32, 91-96.

Hodge, A., Campbell, C.D. \& Fitter, A.H. 2001. An arbuscular mycorrhizal fungus accelerates decomposition and acquires nitrogen directly from organic material. Nature 413, 297-299.

Hodges, C.F. 1978. Postemergent herbicides and the biology of Drechslera sorokiniana: influence on severity of leaf spot on Poa pratensis. Phytopathology 68, 1359-1363.

Hodges, C.F. 1984. Development of Drechslera sorokiniana on sequentially older leaves of Poa pratensis exposed to postemergence herbicide combinations. Plant Disease 68, 213215.

Hodges, C.F. 1992. Vegetative growth and sporulation of Bipolaris sorokiniana on infected leaves of Poa pratensis exposed to postemergence herbicides. Canadian Journal of Botany 70, 568-570.

Hodges, C.F. 1994. Vegetative growth and sporulation of Bipolaris sorokiniana on sequentially older infected leaves of Poa pratensis exposed to postemergence herbicides. Mycopathologia 128, 105-109.

Holley, J.D. \& Peterson R.L. 1979. Development of a vesicular-arbuscular mycorrhiza in bean roots. Canadian Journal of Botany 57, 1960-1978.

Hooker, J.E., Jaizme-Vega, M. \& Atkinson, D. 1994. Biocontrol of plant pathogens using mycorrhizal fungi. In: Impact of mycorrhizas on sustainable agriculture and natural ecosystems. (Eds. S Gianinazzi \& Schüepp). Birkhäuser Verlag, Basel, Switzerland, pp. 191-200.

Howeler, R.H., Sieverding, E. \& Saif, S. 1987. Practical aspects of mycorrhizal technology in some tropical crops and pastures. Plant and Soil 100, 249-283.

Hännig, 1904. Zur physiologie pflanzlicher embyonen. Botanische Zeitung 62, 45-80.

Jabaji-Hare, S. 1988. Lipid and fatty acid profiles of some vesicular-arbuscular mycorrhizal fungi: contribution to taxonomy. Mycologia 80, 622-629.

Jakobek, J.L. \& Lindgren, P.B. 1993. Generalized induction of defense responses in bean is not correlated with the induction of the hypersensitive reaction. The Plant Cell 5, 49-56.

Jakobsen, I. \& Nielsen, N.E. 1983. Vesicular-arbuscular mycorrhiza in field-grown crops I; Mycorrhizal infection in cereals and peas at various times and soil depths. New Phytologist 93, 401-413.

Janos, D.P. 1980. Mycorrhizae influence tropical succession. Biotropica 12, 56-64.

Janos, D.P. 1993. Vesicular-arbuscula mycorrhizae of epiphytes. Mycorrhiza 4, 1-4.

Jansa, J., Mozafar, A., Anken, T., Ruh, R., Sanders, I.R. \& Frossard, E. 2002. Diversity and structure of AMF communities as affected by tillage in a temperate soil. Mycorrhiza 12, 225-234.

Jeffries, P., Spyropoulos, T. \& Vardavarkis, E. 1988. Vesicular-arbuscular mycorrhizal status of various crops in different agricultural soils of northern Greece. Biology and Fertility of Soils 5, 333-337.

Jenns, A.E. \& Kuc, J. 1977. Localized infection with tobacco necrosis virus protects cucumber against Colletotrichum lagenarium. Physiological Plant Pathology 11, 207212

Jensen, A. \& Jakobsen, I. 1980. The occurrence of vesicular-arbuscular mycorrhiza in barley and wheat grown in some Danish soils with different fertilizer treatments. Plant and Soil 55, 403-414.

Johnson, N.C. 1993. Can fertilisation of soil select less mutualistic mycorrhizae. Ecological Applications 3, 749-757.

Johnson, N.C., Graham, J.H. \& Smith, F.A. 1997. Functioning of mycorrhizal associations along the mutualism-parasitism continuum. New Phytologist 135, 575-585. 
Johnson, D., Leake, J.R., Ostle, N., Ineson, P. \& Read, DJ. 2002. In situ ${ }^{13} \mathrm{CO}_{2}$ pulselabelling of upland grassland demonstrates a rapid pathway of carbon flux from arbuscular mycorrhizal mycelia to the soil. New Phytologist 153, 327-334.

Johnson, N.C. \& Pfleger, F.L. 1992. Vesicular-arbuscular mycorrhizae and cultural stresses. In: Mycorrhizae in sustainable agriculture. (Eds. G.J. Bethlenfalvay \& R.G. Linderman) ASA special publication 54, pp. 71-99.

Johnson, N.C., Copeland, P.J., Crookston, R.K. \& Pfleger, F.L. 1992. Mycorrhizae: Possible explanation for yield decline with continous corn and soybean. Agronomy Journal 84, 387-390.

Johnson, N.C., Zak, D.R., Tilman, D. \& Pfleger, F.L. 1991. Dynamics of vesiculararbuscular mycorrhizae during old field succession. Oecologia 86, 349-358.

Johnson, D., Leake, J.R., Ostle, N., Ineson, P. \& Read, D.J. 2002. In situ ${ }^{13} \mathrm{CO}_{2}$ pulselabelling of upland grassland demonstrates a rapid pathway of carbon flux from arbuscular mycorrhizal mycelia to the soil. New Phytologist 153, 327-334.

Jørgensen, J. 1974. Occurrence and importance of seed borne inoculum of Cochliobolus sativus in Denmark. Acta Agriculture Scandinavica 24, 49-54.

Kabir, Z., O'Halloran, I.P., Fyles, J.W. \& Hamel, C. 1998. Dynamics of the mycorrhizal symbiosis of corn (Zea mays L.): effects of host physiology, tillage practices and fertilisation on spatial distribution of extra-radical mycorrhizal hyphae in the field. Agriculture, Ecosystem and Environment 68, 151-163.

Kabir, Z., O'Halloran, I.P. \& Hamel, C. 1997. Overwinter survival of arbuscular mycorrhizal hyphae is favoured by attachment to roots but diminished by disturbance. Mycorrhiza 7, 197-200.

Kahiluoto, H., Ketoja, E., Vestberg, M. \& Saarela, I. 2001. Promotion of AM utilization through reduced P fertilization II; Field studies. Plant and Soil 231, 65-79.

Kamienski, F. 1881. Die Vegetationsorgane der Monotropa hypopitys L. Botanische Zeitung 39, 457-461. (In German)

Karagiannidis, N., Bletsos, F. \& Stavropoulos, N. 2002. Effect of Verticillium wilt (Verticillium dahliae Kleb.) and mycorrhiza (Glomus mosseae) on root colonization, growth and nutrient uptake in tomato and eggplant seedlings. Scientia Horticulturae 94, $145-156$

Karasawa, T., Kasahara, Y. \& Takebe, M. 2001. Variable response of growth and arbuscular mycorrhizal colonization of maize plants to preceding crops in various types of soils. Biology and Fertility of Soils 33, 286-293.

Kesava, R.P.S., Tilak, K.V.B.R. \& Arunachalam, V. 1990. Genetic variation for VA mycorrhiza-dependent phosphate mobilization in groundnut (Arachis hypogaea L.) Plant and Soil 122, 137-142.

Kling, M. \& Jakobsen, I. 1997. Direct application of carbendazim and propiconazole at field rates to the external mycelium of three arbuscular mycorrhizal fungi species: effect on ${ }^{32} \mathrm{P}$ transport and succinate dehydrogenase activity. Mycorrhiza 7, 33-37.

Klironomos, J.N. 2003. Variation in plant response to native and exotic arbuscular mycorrhizal fungi. Ecology 84, 2292-2301.

Knudsen, I.M.B., Hockenhull, J. \& Jensen, D.F. 1995. Biocontrol of seedling diseases of barley and wheat caused by Fusarium culmorum and Bipolaris sorokiniana: effects of selected fungal antagonists on growth and yield components. Plant Pathology 44, 467477.

Knudsen, I.M.B., Hockenhull, J., Jensen, D.F., Gerhardson, B., Hökeberg, M., Tahvonen, R., Teperi, E., Sundheim, L. \& Henriksen, B. 1997. Selection of biological control agents for controlling soil and seed-borne diseases in the field. European Journal of Plant Pathology 103, 775-784.

Koske, R.E. \& Gemma, J.N. 1989. A modified procedure for staining roots to detect VA mycorrhizas. Mycological Research 92, 486-505.

Krishna, K.R., Shetty, K.G., Dart, P.J. \& Andrews, D.J. 1985. Genotype dependent variation in mycorrhizal colonization and response to inoculation of pearl millet. Plant and Soil 86, 113-125.

Kruckelmann, H.W. 1975. Effects of fertilizers, soils, soil tillage, and plant species on the frequency of Endogone chlamydospores and mycorrhizal infection in arable soils. In: 
Endomycorrhizas. (Eds. FE Sanders, B Mosse, PB Tinker) Academic Press, London, UK, pp. 511-525.

Kubota, M., McGonigle, T.P. \& Hyakumachi, M. 2005. Co-occurrence of Arum- and Paristype morphologies of arbuscular mycorrhizae in cucumber and tomato. Mycorrhiza 15, 73-77.

Kuc, J. 1987. Plant immunization and its applicability for disease control. In: Innovative approaches to plant disease control. (Ed. I Chet) John Wiley, New Yourk, USA. pp. 255274.

Kurppa, A. 1984. Bipolaris sorokiniana on barley seed in Finland. Journal of Agricultural Science in Finland 56, 175-182.

Kurppa, A. 1985. Reaction of spring barley cultivars grown in Finland to soil-borne infection by Bipolaris sorokiniana and to its toxic metabolites. Journal of Agricultural Science in Finland 57, 85-96.

Land, S. \& Schönbeck, F. 1991. Influence of different soil types on abundance and seasonal dynamics of vesicular arbuscular mycorrhizal fungi in arable soils of North Germany. Mycorrhiza 1, 39-44.

Lange, W. 1969. Cytogenetisch en embryologisch onderzoek aan kruisingen tussen Hordeum vulgare en $H$. bulbosum. Doctoral thesis. Verslagen Landbouwkundige Onderzoekingen 719. Wageningen, the Netherlands. (In Dutch)

Larsen, J. \& Bødker, L. 2001. Interactions between pea root-inhabiting fungi examined using signature fatty acids. New Phytologist 149, 487-493.

Ledingham, R.J. 1961. Crop rotations and common root rot in wheat. Canadian Journal of Plant Science 41, 479-486.

Lee, S.S. 1986. Toxic metabolites produced by Helminthosporium sativum. Thesis. Department of plant pathology. North Dacota State University of Agriculture and Applied Science.

Lemanceau, P., Samson, R. \& Alabouvette, C. 1988. Recherches sur la resistance des sols aux maladies, XV-Comparisons des populations de Pseudomonas fluorescent dans un sol resistant et un sol sensible aux fusarioses vasculaires. Agronomie 8, 243-249. (In French)

Liljeroth, E. \& Bryngelson, T. 2002. Seed treatment of barley with Idriella bolleyi causes systematically enhanced defence against root and leaf infection by Bipolaris sorokiniana. Biocontrol Science and Technology 12, 235-249.

Linderman, R.G. 1994. Role of VAM fungi in biocontrol. In: Mycorrhiza and plant health. (Eds. F.L. Pfelger \& R.G. Linderman). APS Press, St. Paul, USA, pp. 1-25.

Linderman, R.G. \& Paulitz, T.C. 1990. Mycorrhizal-rhizobacterial interactions. In: Biological control of soil-borne plant pathogens. (Ed. D Hornby). CAB International, Wallington, UK, pp. 261-283.

Lingua, G., Dágostino, G., Massa, N., Antosiano, M. \& Berta, G. (2002) Mycorrhizainduced differential response to a yellows disease in tomato. Mycorrhiza 12, 191-198.

Mansfeld-Giese, K., Larsen, J. \& Bødker, L. 2002. Bacterial populations associated with mycelium of the arbuscular mycorrhizal fungus Glomus intraradices. FEMS Microbiology Ecology 41, 133-140.

Manske, G.G.B. 1990. Genetical analysis of the efficiency of VA mycorrhiza with spring wheat. Agriculture, Ecosystems and Environment 29, 273-280.

Mark, G.L. \& Cassells, A.C. 1996. Genotype-dependence in the interaction between Glomus fistulosum, Phytophthora fragariae and the wild strawberry (Fragaria vesca). Plant and Soil 185, 233-239.

Marrè, E. 1980. Mechanism of action of phytotoxins affecting plasmalemma functions. Progress in Phytochemistry 6, 254-284.

Mårtensson, A.M. \& Carlgren, K. 1994. Impact of phosphorus fertilization on VAM diasporas in two Swedish long-term field experiments. Agriculture, Ecosystems and Environment 47, 327-334.

Matsubara, Y., Kayukawa, Y., Yano, M. \& Fukui, H. 2000. Tolerance of asparagus seedlings infected with arbuscular mycorrhizal fungus to violet root rot caused by Helicobasidium mompa. Journal of Japanese Society of Hortocultural Sciences 69, 552556. 
Matsubara, Y., Ohba, N. \& Fukui, H. 2001. Effect of arbuscular mycorrhizal fungus infection on the incidence of Fusarium root rot in asparagus seedlings. Journal of Japanese Society of Hortocultural Sciences 70, 202-206.

McAllister, C.B., García-Garrido, J.M., García-Romera, I., Godeas, A. \& Ocampo, J.A. 1996. In vitro interactions between Alternaria alternata, Fusarium equiseti and Glomus mosseae. Symbiosis 20, 163-174.

McAllister, C.B., García-Romera, I., Martin, J., Godeas, A. \& Ocampo, J.A. 1995. Interaction between Aspergillus niger (van Tiegh.) and Glomus mosseae (Nicol. \& Gerd.) Gerd. \& Trappe. New Phytologist 129, 309-316.

McGonigle, T.P. 1988. A numerical analysis of published field trials with vesiculararbuscular mycorrhizal fungi. Functional Ecology 2, 473-478.

McGonigle, T.P. \& Miller, M.H. 1999. Winter survival of extraradical hyphae and spores of arbuscular mycorrhizal fungi in the field. Applied Soil Ecology 12, 41-50.

Mead, H.W. 1942. Environmental relationship in a seed-borne disease of barley caused by Helminthosporium sativum Pammel, King \& Bakke. Canadian Journal of Research 20, 525-538.

Mehta, Y.R. 1997. Constraints on the integrated management of Spot blotch of wheat, pp. 18-27. In: Helminthosporium blight of wheat: Spot Blotch and Tan Spot, pp. 18-27. (Eds. E. Duveiller, H.J. Dubin, J. Reeves \& A. McNab). Proceedings of an international workshop held at CIMMYT, 9-14 February 1997. El Batan, Mexico. ISBN 970-648-0013 .

Menge, J.A., Johnson, E.L.V. \& Minassian, V. 1979. Effect of heat treatment and three pesticides upon the growth and reproduction of the mycorrhizal fungus Glomus fasciculatus. New Phytologist 82, 473-480.

Mercier, J. \& Wilson, C.L. 1994. Colonization of apple wounds by naturally occurring microflora and introduced Candida oleophila and their effect on infection by Botrytis cinerea during storage. Biological Control 4, 138-144.

Meyer, J.M. \& Dehne, H.W. 1986. The influence of VA mycorrhizae on biotrophic leaf pathogens. In: Physiological and genetical aspects of mycorrhizae. (Eds. V Gianinazzi Pearson \& S Gianinazzi). Institut National de la Recherche Agronomique, Paris, France, pp. 781-786.

Miller, D.D., Domoto, P.A. \& Walker, C. 1985. Mycorrhizal fungi at eighteen apple rootstock plantings in the United States. New Phytologist 100, 379-391.

Modjo HS \& Hendrix JW (1986) The mycorrhizal fungus Glomus macrocarpun as a cause of tobacco stunt disease. Phytopathology 76, 688-691.

Molina, R. 1979. Ectomycorrhizal colonization of containerized Douglas-fir and Lodgepole pine seedlings with six isolates of Pisolithus tinctorius. Forest Science 25, 585-590.

Molina, R., Massicotte, H. \& Trappe, J.M. 1992. Specificity phenomena in mycorrhizal symbiosis: community-ecological consequences and practical implications. In: Mycorrhizal functioning: an integrative plant-fungal process. (Ed. MF Allen). Chapman and Hall, New York, USA, pp. 357-423.

Morel, M.M. \& Martin, G. 1952. Guérison de Dahlias atteints d'une maladie á virus. Comptes rendus hebdomadaires des séances de l'Académie des sciences 235, 1324-1325. (In French)

Mosse, B. \& Hepper, C.M. 1975. Vesicular-arbuscular infections in root organ cultures. Physiological Plant Pathology 5, 215-223.

Mugnier, J. \& Mosse, B. 1987. Vesicular-arbuscular mycorrhizal infection in transformed root-inducing T-DNA roots grown axenically. Phytopathology 77, 1045-1050.

Newman, E.I. 1988. Mycorrhizal links between plants: Their functioning and ecological significance. Advances in Ecological Research 18, 243-270.

Newsham, K.K., Fitter, A.H. \& Watkinson, A.R. 1994. Root pathogenic and arbuscular mycorrhizal fungi determine fecundity of asymptomatic plants in the field. Journal of Ecology 82, 805-814.

Nilsson, P., Åkesson, H., Jansson, H.B. \& Odham, G. 1993. Production and release of the phytotoxin prehelminthosporol by Bipolaris sorokiniana during growth. FEMS Microbiology Ecology 102, 91-98. 
Norman, J.R., Atkinson, D. \& Hooker, J.E. 1996. Arbuscular mycorrhizal fungal-induced alteration to root architecture in strawberry and induced resistance to the root pathogen Phytophthora fragariae. Plant and Soil 185, 191-198.

Norman, J.R. \& Hooker, J.E. 2000. Sporulation of Phytophthora fragariae shows greater stimulation by exudates of non-mycorrhizal than mycorrhizal strawberry roots. Mycological Research 104, 1069-1073.

Oehl, F., Sieverding, E., Ineichen, K., Mäder, P., Boller, T. \& Wiemken, A. 2003. Impact of land use intensity on the species diversity of arbuscular mycorrhizal fungi in agroecosystems of central Europe. Applied and Environmental microbiology 69, 28162824.

Olofsson, B. 1976. Investigations on Drechslera species in barley and oats. Meddelanden Statens växtskyddsanstalt 16 (172), 323-425. (In Swedish with English summary)

Olvång H (2002) Utsädesburna sjukdomar på jordbruksväxter och skadedjur som motverkas genom betning. Jordbruksverket, Jordbruksinformation 8-2000, 2:a upplagan, KalmarSund Tryck, Kalmar, Sweden. (In Swedish)

Paul, E.A. \& Kucey, R.M.N. 1981. Carbon flow in plant microbial associations photosynthesis. Science 213, 473-474.

Pearson, J.N. \& Jakobsen, I. 1993. The relative contribution of hyphae and roots to phosphorus uptake by arbuscular mycorrhizal plants, measured by dual labelling with ${ }^{32} \mathrm{P}$ and ${ }^{33}$ P. New Phytologist 124, 489-494.

Perry DA, Amaranthus MP, Borchers JG, Borchers SL \& Brainers RE (1989) Bootstrapping in ecosystem. Bioscience 39, 230-237.

Piening, L.J. 1973. Differential yield response of ten barley cultivars to common root rot. Canadian Journal of Plant Sciences 53, 763-764.

Plenchette, C., Fortin, J.A. \& Furlan, V. 1983. Growth response of several plant species to mycorrhizae in a soil of moderate P-fertility I; Mycorrhizal dependency under field conditions. Plant and Soil 70, 199-209.

Rabatain, S.C. \& Stinner, B.R. 1989. The significance of vesicular-arbuscular mycorrhizal fungi-soil macroinvertebrate interactions in agroecosystems. Agriculture Ecosystem and Environment 27, 195-204

Raemaekers, R. 1991. Contribution to the epidemiology of Bipolaris sorokiniana diseases and the development of rainfed wheat, a new crop in Zambia. Dissertationes de agricultura, faculteit der landbouwwetenschappen, katholieke universiteit te Leuven, Belgium.

Read, D.J. 1992. The mycorrhizal mycelium. In: Mycorrhizal Functioning. (Ed. MF Allen) Chapman and Hall, London, UK, pp. 102-133.

Read, D.J. 1998. Mycorrhiza - the state of the art. In: Mycorrhiza: structure, function, molecular biology and biotechnology. (Eds. A Varma \& B Hock). Springer-Verlag, Berlin, Germany.

Read, D.J. 2002. Towards ecological relevance - progress and pitfalls in the path towards an understanding of mycorrhizal functions in nature. In: Mycorrhizal ecology. (Eds. MGA van der Heijden \& IR Sanders). Ecological studies 157. Springer-Verlag, Berlin, Germany, pp. 3-29.

Read, D.J., Francis, R. \& Finlay, R.D. 1985. Mycorrhizal mycelia and nutrient cycling in plant communities. In: Ecological interactions in soil. (Eds. AH Fitter, D Atkinson, DJ Read and MB Uscher). Blackwell Scientific, Oxford, UK, pp. 193-217.

Read, D.J., Koucheki, H.K. \& Hodgson, J. 1976. Vesicular-arbuscular mycorrhiza in natural vegetation systems I; The occurrence of infection. New Phytologist 77, 641-653.

Redecker, D., Kodner, R. \& Graham, L.E. 2000. Glomalean fungi from the Ordovician. Science 289, 1920-1921.

Redhead, J.F. 1977. Endotrophic mycorrhizas in Nigeria: species of Endogonaceae and their distribution. Transactions of the British Mycological Society 69, 275-280.

Reeves, F.B., Wagner, D., Moorman, T. \& Kiel, J. 1979. The role of endomycorrhizae in revegetation practices in the semi-arid west I; A comparison of incidence of mycorrhizae in severely disturbed vs. natural environments. American Journal of Botany 66, 6-13. 
Reis, E.M. 1990. Control of diseases of small grains by rotation and management of crop residues in southern Brazil. Proceedings of the international workshop on conservation tillage systems, Passo Fundo, Brazil, pp. 140-146.

Remy, W., Taylor, T.N., Hass, H. \& Kerp, H. 1994. Four hundred million-years-old vesicular arbuscular mycorrhizae. Proceedings of the National Academy of Science, USA 91, 11841-11843.

Rivera-Becerril, F., Calantzis, C., Turnau, K., Caussanel, J.-P., Belimov, A.A., Gianinazzi, S., Strasser, R.J. \& Gianinazzi-Pearson, V. 2002. Cadmium accumulation and buffering of cadmium-induced stress by arbuscular mycorrhiza in three Pisum sativum L. genotypes. Journal of Experimental Botany 53, 1177-1185.

Roberts, R.G. 1990. Postharvest biological control of gray mold of apple by Cryptococcus laurentii. Phytopathology 80, 526-530.

Ross, J.P. 1972. Influence of Endogone mycorrhiza on phytophthora rot of soybean. Phytopathology 62, 896-897.

Rovira, A.D. 1969. Plant root exudates. Botanical Review 35, 35-57.

Rovira, A.D. \& Davey, C.B. 1974. Biology of the rhizosphere. In: The plant root and its environment. (Ed. EW Carson). University Virginia Press, Charlottesville, USA, pp.153204.

Russell, J. \& Bulman, S. 2005. The liverwort Marchantia foliacea forms a specialized symbiosis with arbuscular mycorrhizal fungi in the genus Glomus. New Phytologist 165, 567-579.

Ryals J, Uknes S \& Ward E (1994) Systemic acquired resistance. Plant Physiology 104, 1109-1112.

Ryals, J.A., Neuenschwander, U.H., Willits, M.G., Molina, A., Steiner, H-Y. \& Hunt, M.D. (1996) Systemic acquired resistance. The Plant Cell 8, 1809-1819.

Ryder, T.B., Hedrick, S.A., Bell, J.N., Liang, X., Clouse, S.D. \& Lamb, C.J. 1987. Organization and differential activation of a gene family encoding the plant defense enzyme chalcone synthase in Phaseolus vulgaris. Molecular and General Genetics 210, 219-233.

Saari, E.E. 1997. Leaf Blight diseases and associated soilborne fungal pathogens of wheat in South and Southeast Asia. In: Helminthosporium blight of wheat: Spot Blotch and Tan Spot, pp. 37-51. (Eds. E Duveiller, HJ Dubin, J Reeves \& A McNab). Proceedings of an international workshop held at CIMMYT, 9-14 February 1997. El Batan, Mexico. ISBN 970-648-001-3.

Saif, S.R. 1986. Vesicular-arbuscular mycorrhizae in tropical forage species as influenced by season, soil texture, fertilizers, host species and ecotypes. Angewandte Botanik 60 , 125-139.

Schenck, N.C. \& Péres, Y. 1990. Manual for the identification of VA mycorrhizal fungi, 3rd edition. Synergistic Publications, Gainesville, Florida, USA. 241 pp.

Schenck, N.C., Siqueira, J.O. \& Oliveira, E. 1989. Changes in the incidence of VA mycorrhizal fungi with changes in ecosystems. In: Interrelationship between microorganisms and plants in soil. (Eds. V Vancura \& F Kunc) Elseiver, New York, USA, pp. 125-129.

Scher, F.M. \& Baker, R. 1982. Effect of Pseudomonas putida and a synthetic iron chelator on induction of soil suppressiveness to fusarium wilt pathogens. Phytopathology 72, $1567-1573$.

Schüßler, A., Schwarzott, D. \& Walker, C. 2001. A new fungal phylum, the Glomeromycota: phylogeny and evolution. Mycological Research 105, 1413-1421.

Schüßler, A. 2005. http:// www. tu-darmstadt. de/ fb/ bio/ bot/ schuessler/ amphylo/ amphylogeny.html (Read August 2005)

Shachar-Hill, Y., Pfeffer, P.E., Douds, D., Osman, S.F., Doner, L.W. \& Ratcliffe, R.G. 1995. Partitioning of intermediate carbon metabolism in VAM colonized leek. Plant Physiology 108, 7-15.

Shaul, O., Galili, S., Volpin, H., Ginzberg, I., Elad, Y., Chet, I. \& Kapulnik, Y. 1999. Mycorrhiza-induced changes in disease severity and PR protein expression in tobacco leaves. Molecular Plant-Microbe Interactions 12, 1000-1007. 
Sieverding, E. 1990. Ecology of VAM fungi in tropical agroecosystems. Agriculture, Ecoosystems and Environment 29, 369-390.

Siqueira, J.O., Colozzi-Filho, A. \& Oliveira, E. 1989. Occurencia de micorrizas vesiculoarbusculares em agro e ecossistemas naturais do estado de minas gerais. Pesquisa Agropecuaria Brasileira 24, 1499-1506. (In Portuguese)

Sivanesan, A. \& Holliday, P. 1981. Cochliobolus sativus. CMI Descriptions of pathogenic fungi and bacteria 71 (701).

Smith, S.E. \& Dickson, S. 1991. Quantification of active vesicular-arbuscular mycorrhizal infection using image analysis and other techniques. Australian Journal of Plant Physiology 18, 637-648.

Smith, S.E. \& Read, D.J. 1997. Mycorrhizal Symbiosis. 2nd edition. Academic Press, San Diego, USA. 605 pp.

Solaiman, M.D. \& Saito, M. 1997. Use of sugars by intraradical hyphae of arbuscular mycorrhizal fungi revealed by radiorespirometry. New Phytologist 136, 533-538.

Spanu, P., Boller, T., Ludwig, A., Wiemken, A., Faccio, A. \& Bonfante-Fasolo, P. 1989. Chitinase in roots of mycorrhizal Allium porrum: regulation and location. Planta 177, 447-455.

Spanu, P. \& Bonfante-Fasolo, P. 1988. Cell wall bound peroxidase activity in roots of mycorrhizal Allium porrum L. New Phytologist 109, 119-124.

Sprague, R. 1950. Diseases of cereals and grasses in North America. Ronald Press, New York, USA.

Spurr, H.W. \& Kiesling, R. 1961. Field and host studies of parasitism by Helminthosporium sorokinianum. Plant Disease Reporter 45, 941-943.

St-Arnaud, M., Hamel, C., Vimard, B., Caron, M. \& Fortin, J.A. 1997. Inhibition of Fusarium oxysporum f. sp. dianthi in the non-VAM species Dianthus caryophyllus by coculture with Tagetes patula companion plants colonized by Glomus intraradices. Canadian Journal of Botany 75, 998-1005.

Stack, R.W. 1982. Yield losses in spring barley due to common root rot in Eastern North Dakota. Phytopathology 72, 1139-1140.

Statistics Sweden. 2000. Yearbook of agricultural statistics, Bulls Tryckeriaktiebolag, Halmstad, Sweden. (In Swedish with English summary)

Statistics Sweden. 2004. Yearbook of agricultural statistics 2004 including food statistics, SCB-Tryck, Örebro, Sweden. (In Swedish with English summary)

Stotzky, G. \& Schenck, S. 1976. Observations on organic volatiles from germinating seeds and seedlings. American Journal of Botany 63, 798-805.

Sutton, J.C. \& Sheppard, B.R. 1976. Aggregation of sand dune soil by endomycorrhizal fungi. Canadian Journal of Botany 54, 326-333.

Sylvia, D.M. \& Neal, L.H. 1990. Nitrogen affects the phosphorus response of VA mycorrhiza. New Phytologist 115, 303-310.

Tester, M., Smith, S.E. \& Smith, F.A. 1987. The phenomenon of "nonmycorrhizal" plants. Canadian Journal of Botany 65, 419-431.

Thompson, J.P. 1987. Decline of vesicular-arbuscular mycorrhizae in long fallow disorder of field crop and its expression in phosphorus deficiency of sunflower. Australian Journal of Agricultural Research 38, 847-867.

Thompson, J.P. 1990. Soil sterilization methods to show VA-mycorrhizae aid P and Zn nutrition of wheat in vertisols. Soil Biology and Biochemistry 22, 229-240.

Thompson, J.P. 1991. Improving the mycorrhizal condition of the soil through cultural practices and effects on growth and phosphorus uptake by plants. In: Phosphorus nutrition of grain legumes in the semi-arid tropics. (Eds. C. Johansen, Lee, K.K. \& Sahrawat, K.L.). International Crops Research Institute for the Semi-Arid Tropics, Andhra Patancheru, India, pp. 117-137.

Thompson, J.P. \& Wildermuth, G.B. 1989. Colonisation of crop and pasture species with vesicular-arbuscular mycorrhizal fungi and a negative correlation with root infection by Bipolaris sorokiniana. Canadian Journal of Botany 67, 687-693.

Tisdall, J.M. 1991. Fungal hyphae and structural stability of soil. Australian Journal of Soil Research 29, 729-743. 
Tisdall, J.M. 1994. Possible role of soil micro-organisms in aggregation of soils. Plant and Soil 159, 115-121.

Tisdall, J.M. \& Oades, J.M. 1979. Stabilisation of soil aggregates by the root systems of ryegrass. Australian Journal of Soil Research 17, 429-441.

Tonin, C., Vandenkoornhuyse, P., Joner, E.J., Straczek, J. \& Leyval, C. 2001. Assessment of arbuscular mycorrhizal fungi diversity in the rhizosphere of Viola calaminaria and effect of these fungi on heavy metal uptake by clover. Mycorrhiza 10, 161-168.

Toth, R., Page, T. \& Castleberry, R. 1984. Differences in mycorrhizal colonization of maize selections for high and low ear leaf phosphorus. Crop Science 24, 994-996.

van der Heijden, M.G.A., Klironomos, J.N., Ursic, M., Moutoglis, P., Streitwolf-Engel, R., Boller, T., Wiemken, A. \& Sanders, I.R. 1998a. Mycorrhizal fungal diversity determines plant biodiversity, ecosystem variability and productivity. Nature 396, 69-72.

van der Heijden, M.G.A., Boller, T., Wiemken, A. \& Sanders, I.R. 1998b. Different arbuscular mycorrhizal fungal species are potential determinants of plant community structure. Ecology 79, 2082-2091.

van der Heijden, E.W. \& Kuyper, T.W. 2001. Does origin of mycorrhizal fungus or mycorrhizal plant influence effectiveness of the mycorrhizal symbiosis? Plant and Soil 230, 161-174.

van der Heijden, M.G.A. 2002. Arbuscular mycorrhizal fungi as a determinant of plant diversity: in search of underlying mechanisms and general principles. In: Mycorrhizal ecology. (Eds. MGA van der Heijden \& IR Sanders). Ecological studies 157, SpringerVerlag, Berlin, Germany. pp. 243-265.

van Loon, L.C., Bakker, P.A.H. \& Pieterse, C.M.J. 1998. Systemic resistance induced by rhizosphere bacteria. Annual Review of Phytopathology 36, 453-483.

Vandenkoornhuyse, P., Husband, R., Daniell, T. J., Watson, I.J., Duck, J.M., Fitter, A.H. \& Young, J.P.W. 2002. Arbuscular mycorrhizal community composition associated with two plant species in a grassland ecosystem. Molecular Ecology 11, 1555-1564.

Vendrig, J.C. 1956. De levenscyclus van Helminthosporium sativum P., K \& B op tarwe en gerst. Tijdschrift over Plantenziekten 62, 30. (In Dutch)

Vestberg, M. 1995. Occurrence of some Glomales in Finland. Mycorrhiza 5, 329-336.

Vestberg, M. 1999. Occurrence of arbuscular mycorrhizal fungi in different cropping systems at Cochabamba, Bolivia. Agricultural and Food Science in Finland 8, 309-318.

Vierheilig, H., Garcia-Garrido, J.M., Wyss, U. \& Piché, Y. 2000. Systemic suppression of mycorrhizal colonisation of barley roots already colonized by AM fungi. Soil Biology and Biochemistry 32, 589-595.

Vivekanandan, M. \& Fixen, P.E. 1991. Cropping systems effects on mycorrhizal colonization, early growth, and phosphorus uptake of corn. Soil Science Society of American Journal 55, 136-140.

von Ammon, H.U. 1963. Über einige arten aus den Gattungen Pyrenophora fries und Cochliobolus Drechler mit Helminthosporium als Nebenfruchtform. Phytopathologische Zeitschrift 47, 244-300. (In German with English summary)

Walker, C., Mize, C.W. \& McNabb, Jr.H.S. 1982. Populations of endogonaceous fungi at two locations in central Iowa. Canadian Journal of Botany 60, 2518-2529.

Walker, C. \& Trappe, J.M. 1993. Names and epithets in the Glomales and Endogonales. Mycological Research 97, 339-344.

Walker, C. \& Vestberg. M. 1998. Synonymy amongst the arbuscular mycorrhizal fungi: Glomus claroideum, G. maculosum, G. multisubstenum and G. fistulosum. Annals of Botany 82, 601-624.

Warner, A. \& Mosse, B. 1983. Spread of vesicular-arbuscular mycorrhizal fungi between separate root systems. Transaction of the British Mycological Society 80, 353-354.

Whipps, J.M. 2004. Prospects and limitations for mycorrhizas in biocontrol of root pathogens. Canadian Journal of Botany 82, 1198-1227.

Whitfield, F.B., Shea, S.R., Gillen, K.J. \& Shaw, K.J. 1981. Volatile compounds from the roots of Acacia pulchella R. Br. and their effect on Phytophthora cinnamomi Rands. Australian Journal of Botany 29, 195-208.

Whittle, A.M. 1977. Cochliobolus sativus on barley in Scotland. Plant Pathology 26, 67-74. 
Wildermuth, G.B. \& MacNamara, R.B. 1987. Susceptibility of winter and summer crops to root and crown infections by Bipolaris sorokiniana. Plant Pathology 36, 481-491.

Wilson, C.L. \& Wisniewski, M.E. 1989. Biological control of postharvest diseases of fruits and vegetables: an emerging technology. Annual Review of Phytopathology 27, 425-441.

Wisniewski, M.E., Wilson, C.L. \& Hershberger, W. 1989. Characterization of inhibition of Rhizopus stolonifer germination and growth by Enterobacter cloacae. Canadian Journal of Botany 67, 2317-2323

Wyss, P., Boller, T.H. \& Wiemken, A. 1992. Testing the effect of biological control agents on the formation of vesicular arbuscular mycorrhiza. Plant and Soil 147, 159-162.

Yadav B (1981) Behaviour of Cochliobolus sativus during its infection of barley and wheat leaves. Australian Journal of Botany 29, 71-79.

Yeung, E.C., Thorpe, T.A. \& Jensen, C.J. 1981. In vitro fertilization and embryo culture. In: Plant tissue culture, methods and applications in agriculture. pp. 253-271. (Ed. Thorpe). Academic Press Inc., New Yourk, USA. Proceedings of a symposium based on the UNESCO training course on plant tissue culture, methods and applications in agriculture, 8-22 November 1978. Sao Paolo, Brazil.

Young, J.L., Davis, E.A. \& Rose, S.L. 1985. Endomycorrhizal fungi in breeder wheats and triticale cultivars fiel-grown on fertile soil. Agronomy Journal 77, 219-224.

Zangerl, A.R. \& Berenbaum, M.R. 1995. Spatial, temporal, and environmental limits on xanthotoxin induction in wild parsnip foliage. Chemoecology 5/6, 37-42.

Zhang, Z. \& Yuen, G.Y. 1999. Biological control of Bipolaris sorokiniana on tall fescue by Stenotrophomonas maltophilia Strain C3. Biological Control 89, 817-822. 


\section{TACKnowledgements}

This project was partially financed by the Swedish Farmers' Foundation for Agricultural Research (SLF).

En rad personer har varit viktiga för att min avhandling nu finns i din hand. Först vill jag tacka min huvudhandledare Anna Mårtensson, en tuff och innovativ forskare med båda fötterna på jorden, men framförallt en handledare som vet hur man får en doktorand att växa som forskare och att ta sig ända fram till hatten! Mitt andra stora tack går till min biträdande handledare doc. Paula Persson som varit med och initierat projektet, kommit med kloka växtpatologiska synpunkter i mitt arbete och varit en god förebild som prefekt. Tack Louise Wärnberg, min mentor, tillika chef på Pharmacia Diagnostics. Du är en bra förebild i ledarskap! Många tänkvärda tankar om chefskap, företag, organisationer och relationer har du generöst delat med dig av. Ett tack också till doc. Sadhna Alström för intressanta diskussioner om interaktioner mellan mikroorganismer. Tack till prof. Jonathan Yuen, som hjälpt mig med statistik och läst artikelutkast och kappa och Dr Annika Djurle, min korridorsgranne, som svarat på alla dessa korta frågor. Tack till Doc. Mette Petersen, Dr Mauritz Vestberg och Prodekanus Jan Stenlid som granskat min avhandling och kommit med tips och synpunkter. Tack också till Hans Olvång, Lennart Johnsson och Christer Svensson för att ni delat med er av eran gedigna erfarenhet av svampsjukdomar på stråsäd! Prof. emeritus Bengt Eriksson, min handledare för examensarbetet om växtpatogena nematoder. Tack för din entusiasm och inspiration för arbete med "miniorganismer" och för att du redan då uppmuntrade mig att doktorera. Ett tack också till er forskare som trots att ni inte varit "mina" handledare ändå brytt er om mitt arbete och min arbetssituation (det lilla är ibland det stora). Ni är goda föredömen; Janne Lagerlöf, Birgitta Rämert och Janne Bengtsson, m.fl. Tack också till Mary McAfee för granskning av engelska språket i mina artiklar och min kappa. Thank you all at the Centre for Mycorrhiza Research, New Delhi, India; Special thanks to Dr. Alok Adholeya, for introducing me to the methods in AM fungal research and for giving me the opportunity to work with your research group, and Dr Reena Singh and Dr Tano (don't forget to contact me when you come to Sweden). Tack också till prof. Roger Finlay, med forskargrupp, för kurs och diskussionstillfällen i ämnet mykorrhiza.

Bland det bästa med doktorandtiden är den speciella sammanhållning man får doktorander emellan. Anuschka Heeb, som vet vad som är viktigt i livet. Jag får tacka dig för alla peppnings samtal vi haft, för att vi delat både glada och "mindre glada" stunder och för att du delade rum med mig. Hanna Friberg, som varit med från början och följt de flesta berg och dalar. Tack för trevliga pratstunder och erfarenhetsutbyten, även i arbetshall och växthus. Eva Blixt, som har den rätta känslan för det livsviktiga, unika, tvärvetenskapliga ämnet Växtpatologi. Tack för att du bryr dig. Maria Viketoft, som visar ett stort engagemang för arbetet trots oändlig tid bakom mikroskopet. Tack bl.a. för våra samtal om intressanta organismer, både fritidsdito och arbetsdito. Maria Björkman, med förkärlek för norra Sverige (eller kanske främst en av dess invånare...) och katter! Tack för den värme du sprider. Tack också till övriga doktorander på och vid institutionen för 
trevliga fikastunder, kurser, taktiksnack, m.m., men främst naturligtvis veteskapliga diskussioner...; Alexandra, Erik, Tomas, C-G, Liv, Sara, Monica m.fl.! Tack också till Anki, Helena, Ingela, Mark och Örjan för att ni gav goda råd och spred både entusiasm och kritiskt tänkande den första tiden. När ni tog era lagerkransar och försvann så blev det liksom lite tomt framför mig på doktorspåret. Några relativt nyblivna doktorer har dock varit behjälplig under senare tid, vad gäller att ge råd och dåd inför avhandlingsarbete och disputation. Jag nämner några (men ni är fler!); Ulla, Niklas, Göran, och sist men viktigast $\mathrm{i}$ denna skara institutionens nya studierektor för forkarutbildningen Birgitta Mannerstedt-Fogelfors. Thank you also all foreign PhD students who have been here full-or part time and enriched the department. Sedan vill jag tacka alla andra förstås på institutionen och i huset som är viktiga länkar för en bra forskning; Janne, Anita, Per, Berit, Ing-Marie, Karin m.fl. Lena Färeby, tiotusen tack för din positiva personlighet och den vägledning du givit vid mitt arbete på lab! Tack också till Anna-Karin Widmark, som har stenkoll på allt på lab, som gärna diskuterar växtpatologiska frågeställningar och som har skänkt oss många berättelser vid fikabordet från sina strapatsrika cykel- och skidsemestrar.

Jag vill även tacka alla i doktorandråd, doktorandnämnd, fakultetsnämnd (2002), samt SLU:s styrelse (2003-2004) för ett lärorikt och trevligt samarbete för SLU:s och forskarutbildningens utveckling. Särskilt tack till Hans Arrendal som gör ett enastående arbete för doktorandernas situation.

Jag vill speciellt tacka; Åsa Bång, vi har lyckats hålla kontakt sedan barnsben och har även haft doktorerandet gemensamt, om än vid olika universitet. Det är guld värt med vänner som $\mathrm{Du}$; Anna Nordblad, vilken lycka att vi började umgås under grundutbildningen. Du är en trevlig, stark kvinna och så likasinnad; Sofia Risberg, min "bästis" från gymnasietiden i Umeå; Lillemor Andersson, en driftig kvinna, tillika en länk till Härnösand, det praktiska jordbruket och dansen. Jag har länge planerat att jag på detta sätt vill tacka Lars Näsholm, Ulla och Hans Bång i orienteringsklubben Umedalens IF. Det var ni som var mina förebilder för agronomyrket. Ulla introducerade mig även till växtpatologin, något som verkade - och visade sig vara - väldigt spännande! Tack också till Anna Ullberg, Christine Schneede, Anna-Karin Johansson, Anna Jakobsson och många fler vänner och släktingar som är viktiga för uppladdning på fritiden...

Det allra viktigaste tacket tillägnar jag mina underbara föräldrar Marianne och Nils-Gunnar; Ni stöttar mig verkligen i allt jag tar mig för. Ni har givit mig en tro på mig själv, även om livet ibland sätter den på prov. Mamma har dessutom hjälpt mig vid min Sverige resa för att samla in jordprover till avhandlingsarbetet. Särskilt tack, postumt, till mina mor- och farföräldrar; Maja och Lage Blomström, samt Alice och Beril Sjöberg som väckt mitt intresse för odling och landsbygd. Ett tack också till min käre bror Jonas och till Hans föräldrar och syskon med familj. Ett extra tack till Dr Annika som känner till doktorerandets vedermödor och den akademiska världen. Till sist ett stort tack till min Hans som har funnits där för mig under hela min doktorandtid och som blivit en mästare $i$ ämnet "Johannavetenskap". 

